\title{
Assessment of the Recovering Effects of Protected Areas Using a Multiple Functional Approaches: The Bamboung Model (Senegal, West Africa)
}

\author{
Djibril FAYE ${ }^{1,2}$ \\ ${ }^{1}$ IRD UMR 195 LEMAR/ RAP (IRD / CNRS/UBO), Centre de Bel-Air, BP 1386, Dakar, Sénégal \\ ${ }^{2}$ Institut Universitaire de Pêche et d'Aquaculture (IUPA), Université Cheikh Anta Diop, Dakar, Sénégal. BP \\ 45784, Dakar, Fann, Sénégal \\ Correspondence: Djibril FAYE, IRD UMR 195 LEMAR/ RAP (IRD / CNRS/UBO), Centre de Bel-Air, BP 1386, \\ Dakar, Sénégal. Tel: 221-338-645-981. E-mail: djibrilfaye682@yahoo.ca
}

\author{
Received: November 24, 2014 Accepted: December 13, $2014 \quad$ Online Published: May 6, 2015 \\ doi:10.5539/ijb.v7n3p37 \\ URL: http://dx.doi.org/10.5539/ijb.v7n3p37
}

\begin{abstract}
The Bamboung protected area (Senegal, West Africa) has been implemented in 2003. However, little is known about its recovering effects on fish assemblage functional diversity. To address this issue, a morphology-based functional grouping was adopted, and results were compared to prior classifications. Functional richness relative to each guild and species abundance was used to define a functional redundancy index. Morphometric measurements were done in the field on freshly killed specimens and completed by digital image processing using the Image-J software in laboratory. Data relative to biomass and abundance were obtained from the IRD (Research Institute for Development) / Adaptive Response of Fish Assemblages to the Environmental Pressure (RAP) Unit-Research database. Hierarchical clustering, analysis using the ward method, was applied to the matrix of morphological traits to discriminate fish assemblages into four functional guilds: zoobenthos feeders, algivorous / detritivorous fish, benthopelagic fish, and demersal and ichthyophagous fish. The new functional grouping reduced fish assemblage complexity to smaller and more significant units than those obtained from previous gut-content based-classification, and the modifications affecting fish biomass distribution after fishing ban, marked by large predatory fishes domination appeared more perceptible. Classification based on fish life-history traits showed similar results with a domination of fish assemblages by marine species of larger size and upper trophic level. However, this latter approach is still relevant as it provides significant information on fish species mobility and community dynamics. Major observed changes occurred after one to three years of protection. The total fish biomass varied from $6458 \mathrm{~kg} \cdot \mathrm{km}^{-2}$ in 2003 to $3114 \mathrm{~kg} \cdot \mathrm{km}^{-2}$ in 2007 . We hypothesized that collapse in total fish biomass may be explained by predation pressure in the system. Species richness varied from 51 in 2003 to 72 in 2007, while the functional redundancy index showed a decreasing trend indicating a functional diversification in the system subsequent to the reserve establishment. The present study highlights the relevance of multiple approaches model in addressing dynamics of complex systems. However, the present trend does not presage the future evolution in the system, many reserves take over a decade to get a stable state.
\end{abstract}

Keywords: ecology, fish assemblages, functional diversity, morphology, protected area, recovering effects

\section{Introduction}

New international policies in resource management are based on an ecosystem approach. In this dynamic, the use of marine protected areas (MPA), or marine reserves as a tool of fishery management and recovery of degraded ecosystems is recommended (Mangel, 2000; Pikitch et al., 2003; Cury et al., 2005, 2008). Several studies have demonstrated their positive impacts in regenerating the taxonomic diversity (Gell \& Roberts, 2003; Abesamis, Russ, \& Alcala, 2006). In response to the new approach, a network of protected areas covering the major West African coastal watersheds has been created. Such initiatives and their integrations in national fishery management policies have been supported by non-governmental organizations (IUCN, WWF, FIBA) under the Five-Years Strategy Regional Program for the Conservation of the Coastal and Marine zone of West Africa (PRCM) signed in 2003.The Bamboung Protected Area (BPA) represents one of the five protected zones created in Senegal since 
then, which extend on over $820 \mathrm{~km}^{2}$. Since their establishments, little is known about their effects in fish assemblage's functional diversity restoration.

Since the studies of Tilman and Downing (1994); Tilman, Lehman, \& Thomson (1997) in North American grasslands, the functional diversity (FD) dimension has emerged as a new paradigm in ecological fields, progressively causing disruption and poor adequacy of taxonomic diversity-based studies. According to many authors (Naeem \& Li, 1997; Loreau \& Hector, 2001; Cardinale et al., 2006), the functional diversity in ecosystems represents the main factor governing their function and production. A high functional redundancy enhances ecosystem resilience and reduce the risk of key function loss (Wellnitz \& Poff, 2001; Rosenfeld, 2002; Nyström, 2006). However, as the paradigm was firstly developed in terrestrial systems, its integration in aquatic ecosystem ecology dated more recently to the 2000s (Hulot, Lacroix, Lescher-Moutoué, \& Loreau, 2000; Dumay, Tari, Tomasini, \& Mouillot, 2004).

In aquatic systems, functional redundancy is driven by the complex interactions between environmental and anthropogenic factors (climatic condition, food availability and fishing activity) and biotic filters like competition and predation (Mouillot, Dumay, \& Tomasini, 2007). Difficulties in understanding the functional effects of marine reserves are fundamentally related to two main factors. Firstly, the variability in fish species response to the protection duration in relation to their life-history traits and the intensity of their exploitations outside the reserve; the larger and target-fishes have often a late sexual maturity scale and low growth rate. In response to these disadvantaged life-history traits, they have more efficient responses to the protected status than smaller species of lower trophic level (Evans \& Russ, 2004; Micheli, Halpern, Botsford, \& Warner, 2004; Floeter, Halpern, \& Ferreira, 2006). Body size is often correlated with trophic level (Jennings \& Mackinson, 2003), and larger species feeding on intermediate levels of food chains are directly targeted by fishers. Thus, fishing has a selective negative effect, as it leads to a decrease in mean trophic levels in yields and in an alteration of whole fish community's structure (Jennings, Pinnegar, Polunin, \& Boon, 2001). The second factor is the transiency in fish assemblage structure which results in fish species ecology and environmental instability. In the Sine Saloum estuary (West Africa), for example, the long history of intensive artisanal fishing activities (Bousso, 1996; Albert \& Laë, 2003), combined with pejorative climate influences (Panfili et al., 2004), has resulted in a loss of $40 \%$ in fish assemblages total biomass and a significant reduction in mean trophic levels of landings (Ecoutin, Simier, Albaret, Laë, \& Tito de Morais, 2010). Understanding how these multiples stressors affect ecosystems processes requires the establishment of relevant metrics enabling to monitor their functional properties and response.

In the West African aquatic ecosystems, the lack of freshwater discharge and the constant marine influence make fish assemblages dissymmetrical, and marine species largely dominated freshwater species (Baran, 2000). Despite the absence of prominent hydrological regime shift, turnover is important in relation to fish species bioecology and environmental conditions (Simier, Blanc, Aliaume, Diouf, \& Albaret, 2004). In response to the natural intense turnover and the transience of trophic relationships, functional categorization of fish assemblages in these estuarine systems is mitigated. Food webs showed a remarkable instability in chain lengths and top predator's taxonomic identity often varied in a seasonal scale (Faye et al., 2011). Despite, this structural variability, trophic groups and life-history strategy based-metrics (i.e. Reproduction, sexual maturity and migration) have been used routinely as a surrogate of functional guilds in ecological studies (Albaret et al., 2004, Elliott et al., 2007) and in fish stock evaluations (Gascuel, Laurans, Sidibé, \& Barry, 2002; Laurans, Gascuel, Chassot, \& Thiam, 2004). However, owing the previewed complexity in systems, both types of categorization presented some specific limitations compromising their lonely utilizations in ecosystems recovering pattern assessments.

Thus, the use of a multiple approach in such ecosystem is recommended (Power, 1999; Adams et al., 2002; Begg et al., 2005). In this perspective, the functional categorization based on fish species morphological features should be relevant as a complementary metric. Morphological traits integration in fish ecology is supported by the premise that in aquatic systems, trophic relationships are fundamentally regulated by body size (Bouton, Van, \& Witte, 1998). More often, predator-prey interactions are ruled by the called Optimal Diet Theory (ODT), which suggest that many predators chose the prey which supplied more energy for a lover capturing and handling process costs (Sih \& Christensen, 2000). Consequently, many large predators continue to exploit small prey, resulting in an asymmetrical distribution in predators and prey body sizes, however, in the whole community scale the trends are linear (Scharf, Juanes, \& Rountree, 2000). Corollary, body size gives an accurate measure of food webs structure (Cohen, Pimm, Yodzis, \& Saldana, 1993; Neubert, Blumenshine, Duplisea, Jonsson, \& Rashleigh, 2000; Woodward et al., 2005). The relevance of its utilization in the functional characterization of the studied ecosystem has been preliminary confirmed by Faye, Le Loc'h, Thiaw, \& Tito de Morais (2012). However, to our knowledge, the issued functional groups have never been applied to MPA bio-monitoring. Thus, to address this issue, at the national and local levels, the design of a model allowing to discriminate species by their function and role in their environments was a first step. 
Thus the main objectives of the present study is to build new functional groups describing the fish assemblages which would be more relevant to monitor its dynamic than the broad preliminary existing classifications. The new system of classification is based on long term morphological features acquired by fish species through their evolution and niche specialization. Thus, it would be less sensitive to temporal and spatial fluctuations in food availability and nutrient origin, which may impair the gut contents or isotope based analysis. The dynamics in term of biomass distribution among the different functional guilds and its evolution represent the key features of the present study. Firstly, fish species will be classified into functional guilds based on morphological variables. Secondly, patterns in biomass distribution will be examined through the newly constructed guilds and compared to results obtained with the two prior categorizations, derived from gut contents and species life-history-traits analysis. Finally, an index linking the morpho-functional guilds and species abundance will be built to accurately estimate functional redundancy in fish assemblages and its evolution in relation with the protection duration.

\section{Materials and Methods}

\subsection{Study Site}

Located at the center of the Sine-Saloum biosphere reserve (Figure 1), the Bamboung Protected Area was established in 2003. The BPA covers an area of $68 \mathrm{~km}^{2}$ and comprises three distinct zones: a central zone corresponding to the creek water body, adjacent alternately inundated banks which are further replaced by continental areas, the third zone is represented by the confluence with the Diomboss main channel. The creek watershed covers an area of $3 \mathrm{~km}^{2}$, with $15 \mathrm{~km}$ of length and its width varies from 500 to $50 \mathrm{~m}$, while its depth is close to $15.5 \mathrm{~m}$. The vegetation occupying the riverine banks is dominated by paletuvian species including Rhyzophora racemosa, Rhyzophora harrisonii, Rhyzophora mangle and Avicenna africana, which respectively lie in a gradient from the creek edges to the emerged swamps. The climate is characterized by three alternate seasons, the dry, the wet and the intermediate cool one. Freshwater inputs are limited to the underground water flowing from the close Coco Island, which weakly contributes to dampen salinity rise.

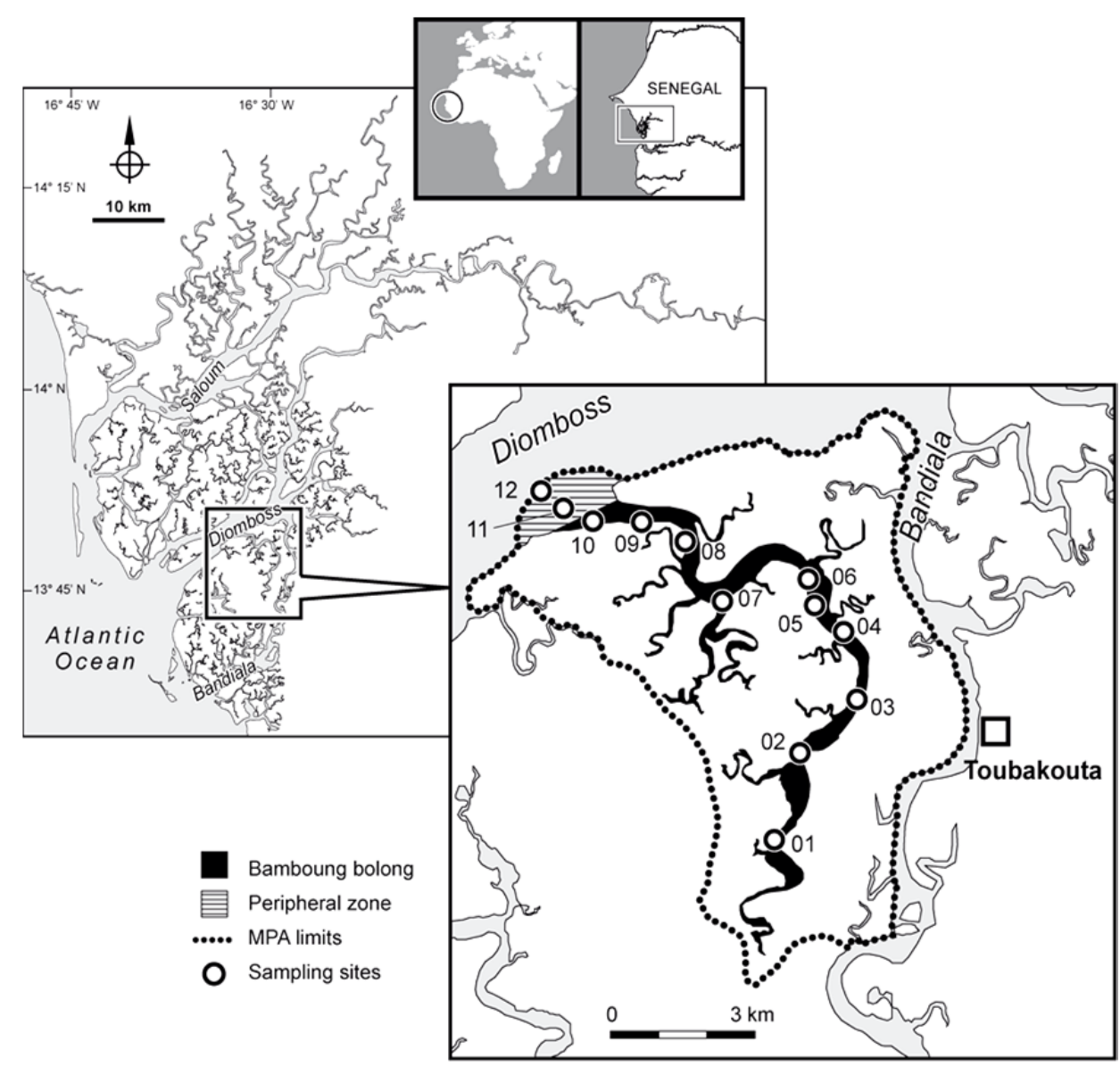

Figure 1. Map of the Sine-Saloum Delta biosphere reserve and the Bamboung creek showing the sampling sites (black circles) 


\subsection{Data Collection}

\subsubsection{Fish Sampling}

Quantitative data relative to fish species abundance and biomass was collected from a database provided by the Research Institute for Development (IRD, France) in the "Narou Heuleuk" Project, funded by the French Global Environmental Fund. Experimental fishing for this project was initiated in 2003, prior to the effective fishing ban. Since then, three additional monitoring campaigns were conducted each year. Fishes were randomly sampled using a purse seine net of $0.005 \mathrm{~km}^{2}$, each site was fished once per trip without targeting shoals. The net was carried by eight fishermen using a motorized boat. For quantitative estimation, all collected material was transferred to a research catamaran serving as a mobile research laboratory. The weight and the number of individuals of each species were recorded after each haul. In 2007, the monitoring protocol was modified and extended to the adjacent fished zones surrounding the protected area. For reasons of homogeneity in the data, the more marginal station (12) which had contrasted physical and biotic characteristics was excluded from the analysis.

\subsubsection{Morphometric Measurements}

Morphometric measurements were conducted on 47 fish species, all inventoried in the Bamboung creek, except the Cichlidae (Hemichromis fasciatus), which was collected from fishermen yielding near the adjacent open fishing creeks. Twenty morphometric measurements relevant to feeding and locomotion functions were measured. Details on their functional significance and technical aspects may be found in early ecomorphological publications (Gatz, 1979, Winemiller, 1991; Sibbing \& Nagelkerke, 2001). For each specimen, electronic Vernier caliper (precision 1/10 mm) was used to measure: mouth height (MH), mouth width (MW), and body width (BW). The Weight (W) of each specimen was accurately determined by a high precision scale. Freshly captured specimens were placed on a square-wooden $\left(1 \mathrm{~cm}^{2}\right)$ plate and a digital image was taken using a Nikon camera for further morphometric measurements. Fishes were then dissected: the first branchial arch and the digestive tract were removed and preserved in $10 \%$ alcohol solution for length measurements. All digital images were processed using the free online-access Image-J software. Morphometric distances were measured and coded as follows: standard length (SL); maximum body depth (MBD); body depth on the pectoral fin insertion (BDPF), horizontal eye diameter (HED); caudal fin depth (CFD); caudal fin surface (CFS); pectoral fin surface (PFS) pectoral fin length (PFL); pectoral fin position (PFP); head depth (HD); mouth position (MP); eye position (EP); caudal peduncle depth (CPD). In the laboratory, maximum gill raker length (GRL) and digestive tract length (DTL) were respectively measured using a microscope fitted with a micrometer and a metal ruler (precision $=1 \mathrm{~mm}$ ). For flat teleost fishes and rays, mouth and eye positions were respectively fixed at 0 and 1 as found in Villéger (2008). For each morphometric distance, a mean value was obtained from five replicates of each fish species.

\subsection{Fish Functional Grouping}

Morphometric distances were transformed into ratios to reduce allometric biases, allowing their functional interpretations (Adite \& Winemiller, 1997). Thus, six functional traits relevant to feeding function and six other ones reflecting the locomotion function were defined (Table 1). The standardization methods were adapted from Villéger (2008). The functional diversity (FD), as defined by Petchey and Gaston (2002) is a measure of species distribution in a space defined by trait dimensions. FD is calculated as the total branch's length of a dendrogram derived from a matrix of $\mathrm{T}$ functional traits and $\mathrm{S}$ species, and belonged to the family of monotonically species richness indices (Walker, Poos, \& Jackson, 2008). Owing to this attribute, the FD is less sensitive to species richness variation and redundancy (Petchey \& Gaston, 2006), while it better explains biomass accumulation (Petchey, Hector, \& Gaston, 2004). The FD dendrogram was obtained by a mean hierarchical cluster analysis (HCA) applied to a matrix crossing 47 fish species and 12 functional trait mean values (Appendix 1). The cluster was performed using the Euclidean distance and the Ward minimum variance clustering method. The derived fish functional groups were termed based on our preliminary knowledge on species trophic and habitat attributes and by analogy with denominations found in Bulman, Althaus, He, Bax, and Williams (2001), and in Coll, Santojanni, Palomera, Tudela, and Ameri (2007). 
Table 1. Transformation of measured morphometric distances into ratios defining twelve functional traits relative to fish locomotion and feeding functions

\begin{tabular}{|c|c|c|c|c|}
\hline Functions & Functional traits & Codes & Ratios & Relevance \\
\hline \multirow{6}{*}{$\begin{array}{l}5 \\
0 \\
0 \\
3 \\
0 \\
\exists \\
0 \\
Z\end{array}$} & Relative eye position & REP & $\frac{\mathrm{EP}}{\mathrm{HD}}$ & $\begin{array}{l}\text { Relative to fish position in the water } \\
\text { column }\end{array}$ \\
\hline & Body transversal shape & BTS & $\frac{\mathrm{MBD}}{\mathrm{BW}}$ & Relative to hydrodynamism \\
\hline & Relative pectoral fin position & PFP & $\frac{\mathrm{PFP}}{\mathrm{BDPF}}$ & Relative to manœuvrability \\
\hline & $\begin{array}{l}\text { Caudal peduncle shrinkage } \\
\text { coefficient }\end{array}$ & PSC & $\frac{\mathrm{MBD}}{\mathrm{CPD}}$ & Relative to endurance \\
\hline & Pectoral fin aspect ratio & PAR & $\frac{\mathrm{PFL}}{\mathrm{PFS}}$ & Relative to manœuvrability \\
\hline & Caudal fin aspect ratio & CAR & $\frac{\mathrm{CFD}}{\mathrm{CFS}}$ & Relative to endurance and speed \\
\hline \multirow{6}{*}{ 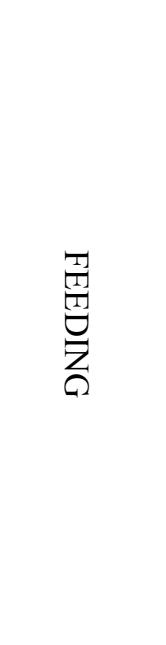 } & Fish weight & LOW & $\log _{10}(W+1)$ & $\begin{array}{l}\text { Proportional to fish feeding rate and its } \\
\text { impact in the environment }\end{array}$ \\
\hline & Relative mouth gap size & RGS & $\frac{\mathrm{MH} \times \mathrm{MW}}{\mathrm{MBD} \times \mathrm{BW}}$ & Relative to maximum prey size \\
\hline & Relative mouth position & RMP & $\frac{\mathrm{MP}}{\mathrm{HD}}$ & $\begin{array}{l}\text { Relative to prey position in the water } \\
\text { column }\end{array}$ \\
\hline & Relative Gill raker length & RGL & $\frac{\mathrm{GRL}}{\mathrm{HD}}$ & Relative to filter feeding \\
\hline & $\begin{array}{l}\text { Relative digestive tract } \\
\text { length }\end{array}$ & RDT & $\frac{\mathrm{DTL}}{\mathrm{SL}}$ & Relative to food digestibility \\
\hline & Relative eye diameter & RED & $\frac{\text { HED }}{\text { HD }}$ & Visual acuity and prey size \\
\hline
\end{tabular}

EP, Eye position; HD, Head depth; MBD, Maximum body depth, BW, Body Width; PFP, Pectoral fin position; BDPF, Body depth at the level of pectoral fin insertion; CPD, Caudal peduncle depth; PFL, Pectoral fin length; PFS, Pectoral fin surface; CFD, Caudal Fin Depth; CFS; Caudal fin surface; W, Fish weight; MH; Mouth height; MW, Mouth Width; MP; Mouth position; HD; Head depth; GRL, Gill raker length; DTL, Digestive tract length; SL, Standard length; HED, Horizontal eye diameter.

Prior to this analysis, the fish species were grouped following the earlier classifications routinely used in the area as described below. Based on Albaret (1994), West African fish assemblages may be partitioned into eight bioecological groups based on their life-history traits (salinity tolerance, time residency, reproductive strategy) distributed along two gradients from a central point composed by the strict estuarine species. The first gradient is that of marine affinity species and includes the estuarine species from marine origin (Em), the marine-estuarine species (ME), and two complementary forms composed of marine species, either accessorily (Ma), or occasionally (Mo) present in estuaries. The continental gradient is not represented in the estuary so we do not describe its composition. Such a classification gives insight on how fish species are temporally distributed in the creek and provides information on their breeding places. While, the functional classification adopted by Diouf (1996), gives information on fish species trophic niches and distinguishes eight groups, including detritivores, herbivores, zooplanktivores, molluscivores, benthic invertebrate feeders, omnivores, top generalist predators and strict piscivores. 


\subsection{Data Manipulation and Analysis}

A preliminary analysis of the data showed that the biomass values had a high variability, potentially related to the differential success in hauling and to seasonal patterns in fish assemblage dynamic. Thus, the patterns of biomass evolution were examined in an annual scale to reduce biases introduced by hauling success variability. Fish species were successively classified according to their morpho-functional guild, their trophic status and their bioecological category. For trophic and bioecological groups, all species recorded in the creek were considered, while for the new guilds the analysis was restricted to species for which, morphological data were available. The omnivorous group was low represented in terms of species richness and biomass proportion and has been excluded from the analysis. For each functional unit, the total weight caught per campaign was obtained by summing the weight (in grams) of all fish species across the 11 sampled sites as follows:

$$
\mathrm{Y}_{\mathrm{cp}}=\sum_{\mathrm{i}=1}^{11} \mathrm{y}_{\mathrm{sh}}
$$

Where, $Y_{\mathrm{cp}}$ represents the weight per campaign (11 sites) of all fish species in a functional group and $\mathrm{y}_{\mathrm{sh}}$ corresponds to the weight per seine haul of all fish species in a functional group.

The total annual weight $(\mathrm{Y})$ was then calculated by aggregating the values of the three campaigns:

$$
\mathrm{Y}=\sum_{\mathrm{i}=1}^{3} \mathrm{Y}_{\mathrm{cp}}
$$

In order to facilitate comparisons with other systems, the aggregated weights were firstly transformed into specific biomass (per unit of area), using the average area swept by the haul (Jackson \& Jones, 1999). Secondly, the biomasses estimated from netting were corrected to consider the gear efficiency. A mean efficiency of $50 \%$, corresponding to a factor of 2 was applied as found in Charles-Dominique (1989). Finally, the total annual biomass caught per functional unit was expressed as follows:

$$
\mathrm{B}\left(\mathrm{kg} \cdot \mathrm{km}^{-2}\right)=\mathrm{a}\left[\frac{\mathrm{Y}}{\mathrm{s}}\right]
$$

Where, B corresponds to the annual biomass $\left(\mathrm{kg} \cdot \mathrm{km}^{2}\right)$ of a functional group; Y represents the total annual weight, $\mathrm{S}\left(0.005 \mathrm{~km}^{2} \mathrm{x} 11\right)$ represents the area swept by the seine net across the 11 sites per campaign and (a) the gear mean efficiency factor.

In complement to our analysis, a weighted abundance functional redundancy index (FRI) was calculated. According to Walker et al. (2008) a weighted index may be more appropriate when rare species are functionally important. The functional redundancy index was calculated on an annual scale, and fish abundance in each functional group was estimated following the same procedure described above. For its parametrization we used an algorithm adapted from Kulbicki (2007), which is described as follows:

$$
\mathrm{FRI}=\frac{1}{\sum_{\mathrm{i}=1}^{\mathrm{n}} \frac{p_{\mathrm{i}}}{\mathrm{FR}}}
$$

Where, $n$ represents the number of morpho-functional groups; $p_{\mathrm{i}}$ the relative abundance of a given functional group, otherwise $p_{i}$ is calculated as the ratio between the number of individuals of a given functional group and the total annual fish abundance. FR represents the richness of a given functional group. Parameter values used to calculate the FRI are reported in Appendix 2.

\section{Results}

\subsection{Morpho-Functional Guilds}

The cluster analysis performed on a matrix of 12 morpho-functional traits allowed to classify the 47 species into four guilds (Figure 2) reflecting the species trophic status, their modes of feeding and their habitats. Quoted in the sense of their average trophic levels the four functional guilds are described as follows:

The guild of algivorous / detritivorous fish which included mullets of the genus Mugil and Liza (excepted Liza dumerili) and cichlids of the genus Tilapia and Sarotherodon. The guild of benthopelagic fish, which is heterogeneous and intermediate in terms of species richness. It included many medium-size pelagic fishes known, either as zooplankton feeders like the Clupeidae (Sardinella aurita, Sardinella maderensis and Ethmalosa fimbriata), or macrocarnivores as Elops lacerta and Ilisha africana. The second component of this group is medium-size benthic fishes as the Gerreidae (Eucinostomus melanopterus), the Haemulidae (Brachydeuterus auritus and Pomadasys incisus), associated with a member of each of these families: 


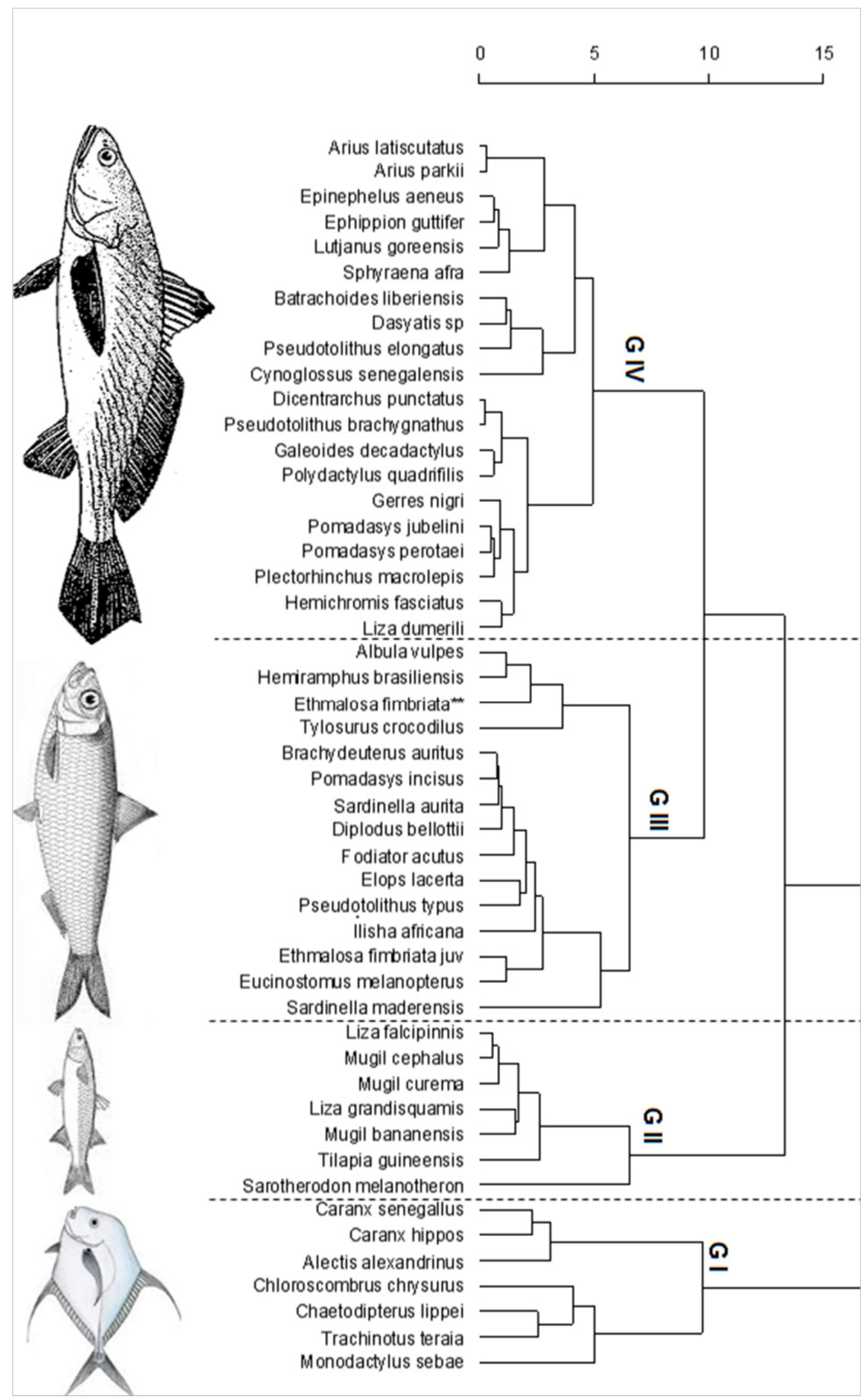

Figure 2. The four morpho-functional guilds identified in the fish assemblage as derived from the cluster grouping analysis using the Euclidean distances and the Ward minimum variance. GI: Zoobenthos feeders; GII: Algivorous / Detritivorous fish; GIII: Benthopelagic fish; GIV: Demersal and Ichthyphagous fish. $\left.{ }^{* *}\right)$ juvenileof $E$. fimbriata 
Albulidae (Albula vulpes), Belonidae (Tylosurus crocodiles), Exocoetidae (Fodiator acutus) and the Sciaenidae (Pseudotholithus typus).

The guild of zoobenthos feeders included demersal fish species with trophic habits based on nektonic prey and other fishes. The major components of this group were species of the Carangidae family (Alectis alexandrinus, Caranx hippos, Caranx senegallus, Chloroscombrus chrysurus and Trachinotus teraia) associated with other relatively small-size species of the Ephippidae and Monodactylidae families.

Finally, the demersal and ichthyophagous fish constituted the largest guild. Species belonging to this guild are known as, either macrocarnivores like Arius latiscutatus, Lutjanus goreensis and Polydactylus quadrifilis or piscivores like Dicentrarchus punctatus, Epinephelus aeneus, Pseudotolithus brachygnathus and Sphyraena afra. Other species known as benthic invertebrate feeders like Batrachoides liberiensis, Dasyatis margarita and Gerres nigri clustered also into this guild. Surprisingly, the mullet $L$. dumerili was associated with this group.

\subsection{Fish Assemblage Response Patterns}

\subsubsection{Based on Morpho-Functional Guilds}

The analysis based on morpho-functional guilds showed a noticeable functional change in fish assemblage occurring in 2006, after three years of protection (Figure 3a). The two main functional guilds in terms of biomass representation showed opposite trends in their evolutions. Thus, the proportion of demersal and ichthyophagous fish which was close to $42 \%$ from 2003 to 2005 moved to $66 \%$, while that of the benthopelagic fish shifted from $38 \%$ to under $20 \%$ and remained stable around this proportion. The biomass proportion of zoobenthos feeders varied following a curved trend with low values in 2003 (3\%) and in $2007(6 \%)$, while in intermediate years their proportions were close to $15 \%$. The faster change occurred in algivorous / detritivorous guild, for which the proportion shifted from 17 to $5 \%$ between 2003 and remained stable around this proportion during the following years (Figure 3a).

\subsubsection{Trophic Groups}

Prior to the MPA establishment in 2003, the total fish specific biomass was $6458 \mathrm{~kg} \cdot \mathrm{km}^{-2}$ (Table 2), and was distributed among 51 fish species belonging to 26 families (Table 3). While, fish assemblage functional composition was characterized by the high proportion of species of lower trophic level, and top predatory fish were low represented. Detritivores and herbivores accounted for 45 and $32 \%$ of the total biomass, while generalist predatory fish and specialized piscivores represented $5 \%$ for each of them (Figure $3 b$ ). The guild of detritivores showed a rapid evolution as their proportions fell to $10 \%$ after one year of protection, and remained around this value. Simultaneously that of the generalist predatory fishes increased and reached 25 and $36 \%$ respectively in 2004 and in 2007 (Figure 3b). Herbivorous guild proportions were stable around $32 \%$ until 2005 and then shifted to under $5 \%$ the following years. While the proportions of piscivores were stable around $7 \%$ (2003 to 2004) and then increased continuously by reaching $30 \%$ of total fish biomass in 2007. Intermediate trophic guilds showed a less more appreciable trends (Figure 3b). In 2003, the three groups, moluscivores, zooplanktivores, and benthic invertebrate feeders, had similar proportions and represented $5 \%$ of total biomass for each of them. The proportion of moluscivores and that of zooplanktivores increased from 2003 to 2004 and reached respectively 15 and $9 \%$ before falling to their initial values. Benthic invertebrate feeder's biomass evolved following a shape curved trend with extreme values close to $10 \%$ and higher intermediated ones ranged between 19 to $20 \%$.

Table 2. Total annual specific biomass $\left(\mathrm{kg} . \mathrm{km}^{2}\right)$ per trophic group in the eleven considered stations (1-11) of the BPA from 2003 to 2007

\begin{tabular}{lllllllll}
\hline Years & He-de & he-ph & p1-bt & p1-mc & p1-zo & p2-ge & p2-pi & Total \\
\hline $\mathbf{2 0 0 3}$ & 2911.1 & 2074.9 & 211.3 & 311.0 & 263.7 & 341.9 & 344.4 & 6458.3 \\
$\mathbf{2 0 0 4}$ & 425.7 & 934.3 & 465.0 & 638.5 & 384.3 & 1030.1 & 280.0 & 4157.9 \\
$\mathbf{2 0 0 5}$ & 268.3 & 1736.1 & 831.7 & 256.1 & 127.0 & 869.4 & 1255.2 & 5343.8 \\
$\mathbf{2 0 0 6}$ & 855.2 & 300.1 & 1114.0 & 176.3 & 349.4 & 2150.9 & 957.8 & 5903.7 \\
$\mathbf{2 0 0 7}$ & 273.8 & 144.4 & 269.0 & 250.7 & 133.2 & 1109.5 & 933.9 & 3114.6 \\
\hline
\end{tabular}

See Figure 3 for codes signification. 

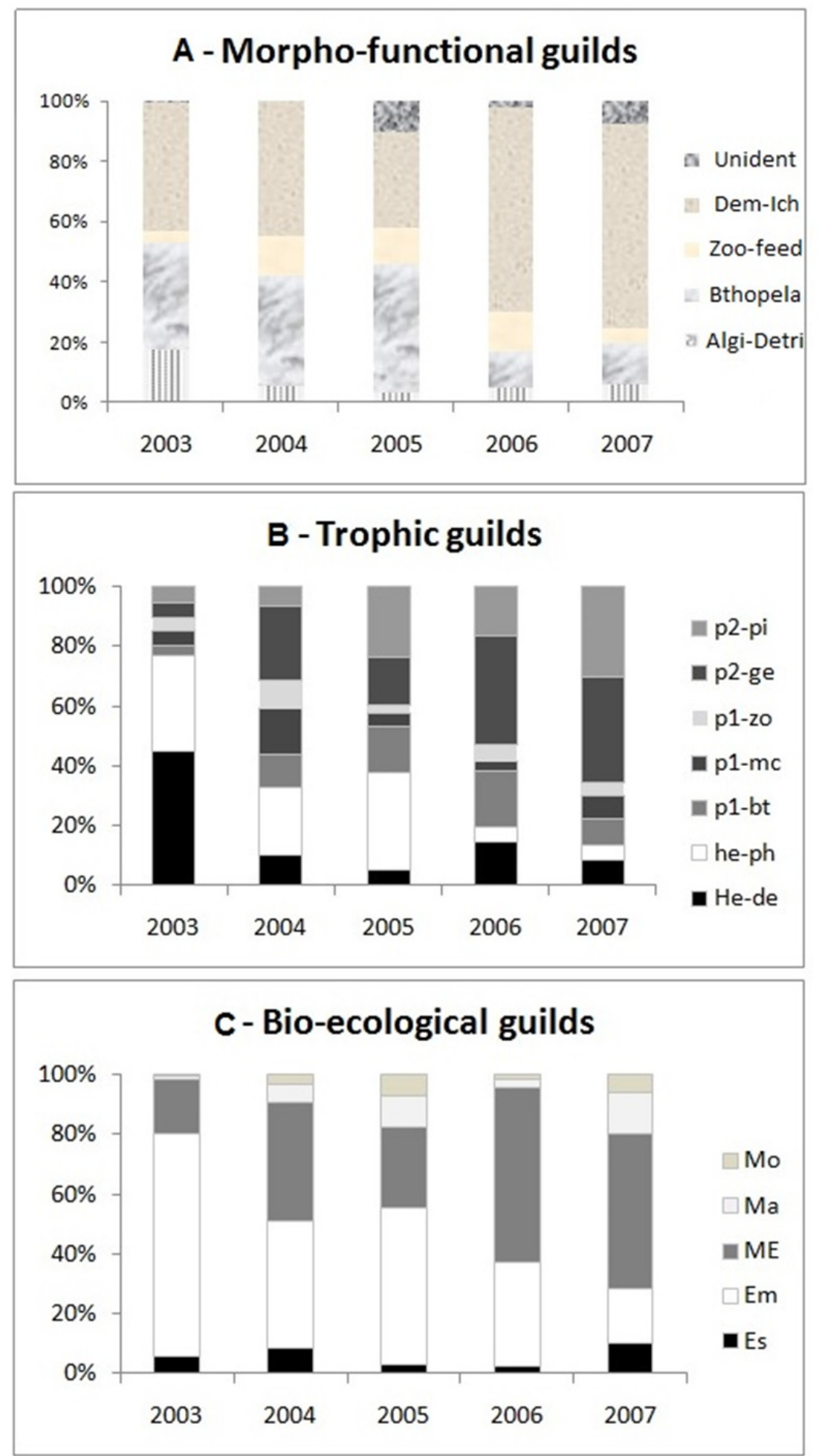

Figure 3. Evolution of Fish assemblage structure in terms of biomass distribution into the different components of each type of functional (morpho-functional trophic, and bio-ecological) guild, from 2003 to 2007. Uniden: Unidentified species, Dem-Ich: Demersal and ichthyophagous fish, Zoo-feed: Zoobenthos feeders, Bthopela: Benthopelagic fish, Algi-Detri: Algivorous /Detritivorous fish. Trophic groups and bioecologcal categories are named as follows: Trophic groups- Hede, detritivores; Heph, herbivores; P1bt, invertebrate feeders; P1mc, Molluscivores; P1zo, Zooplanktivores, P2ge, generalist predators, P2pi, specialized piscivores - Bioecological categories-Es, strictly estuarine species; Em, Estuarine species of marine origin; ME, marine estuarine species; Ma, Marine species accessory in estuaries; Mo, Marine species occasional in estuaries 


\subsubsection{Bioecological Groups}

In 2003, fish assemblages were dominated by estuarine species of marine origin (Em) and marine-estuarine species (ME) representing respectively 75 and $18 \%$ (Figure 3c). Marine species accessorily (Ma) and occasionally (Mo) present in the creek constituted very low proportion of total biomass $(<2 \%)$. After the first year of protection a noticeable modification was observed in the functional composition of fish assemblages. The estuarine species of marine-origin $(\mathrm{Em})$ biomass decreased following a regular trend with proportions varying from 42 to $18 \%$ from 2004 to 2007 (Figure 3c). Simultaneously, marine-estuarine species biomass proportions shifted from 40 to over than $50 \%$. Complementary forms (Ma and Mo) experienced a low increasing trend, their respective proportions varied from 6 to $14 \%$ and from 3 to $6 \%$ between 2004 and 2007. The proportion of the strictly estuarine species remained relatively constant around 6 and $10 \%$ in 2003 and 2007, with intermediate lower values close to $3 \%$ (Figure 3c).

\subsection{Functional Redundancy Evolution}

In summary, twenty one species, mainly of macrocarnivore habits with large to medium body sizes have been recruited in the reserve from 2004 to 2007 (Table 3). Thus, species richness in the creek moved from 51 to 72 after five years of fishing ban. The functional redundancy index varied from 10 to 7 between 2003 and 2007, with intermediate lower values, following thus a relatively linear trend (Figure 4). The annual functional richness was highest in 2004 (45 species) and lowest in the following year (35 species) with an average value of $\sim 38$ species (Appendix 2).

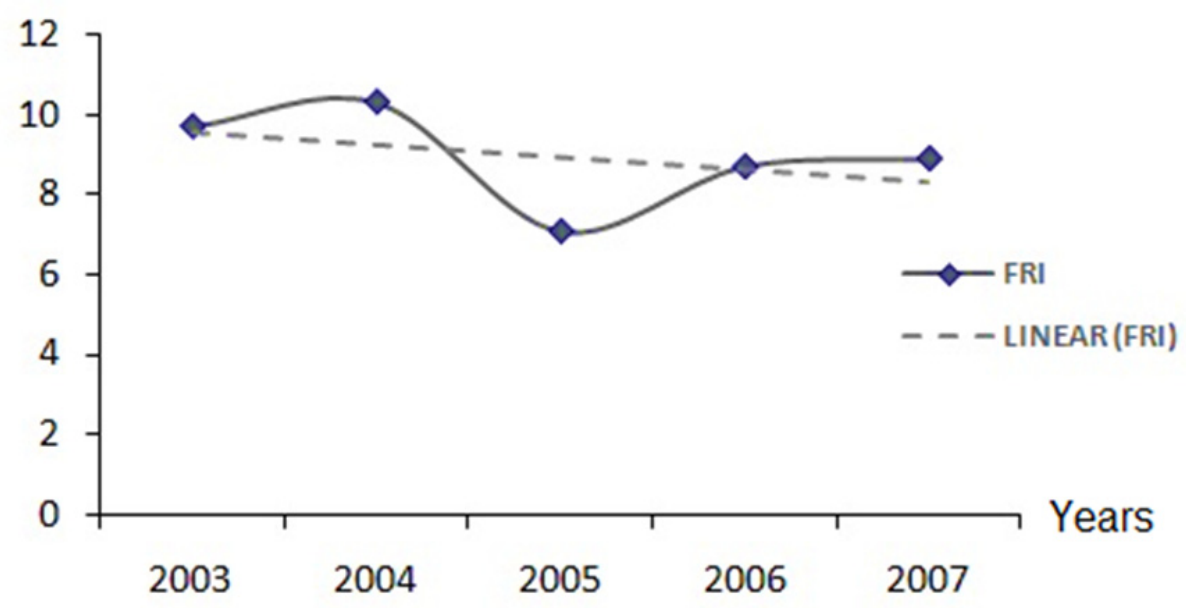

Figure 4. The evolution of the Functional Redundancy Index (FRI, vertical axis) derived from the combination of morphological guilds and fish species abundance (from 2003 to 2007)

Table 3. Fish species recruitment process in the BPA from 2003 to 2007

\begin{tabular}{|c|c|c|c|c|}
\hline Family & Species names & Trophic groups & Bioecol-cat & Years of recruitment \\
\hline Acanthuridae & Acanthurus monroviae & om-ge & Mo & $\bullet$ \\
\hline Albulidae & Albula vulpes & $\mathrm{p} 1-\mathrm{bt}$ & Mo & $\bullet$ \\
\hline \multirow[t]{3}{*}{ Ariidae } & Arius latiscutatus & p2-ge & ME & $\bullet$ \\
\hline & Arius heudelotii & p2-ge & $\mathrm{ME}$ & 2005 \\
\hline & Arius parkii & p2-ge & ME & $\bullet$ \\
\hline Batrachoididae & Batrachoides liberiensis & p2-ge & $\mathrm{Ma}$ & $\bullet$ \\
\hline \multirow[t]{2}{*}{ Belonidae } & Strongylura senegalensis & p2-pi & $\mathrm{Em}$ & $\bullet$ \\
\hline & Tylosurus crocodilus & p2-pi & Mo & $\bullet$ \\
\hline Blenniidae & Hypleurochilus langi & $\mathrm{p} 1-\mathrm{bt}$ & Es & 2005 \\
\hline \multirow[t]{2}{*}{ Carangidae } & Caranx senegallus & p2-ge & ME & $\bullet$ \\
\hline & Caranx hippos & p2-ge & ME & 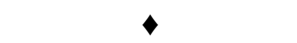 \\
\hline
\end{tabular}




\begin{tabular}{|c|c|c|c|c|}
\hline & Chloroscombrus chrysurus & p1-mc & $\mathrm{ME}$ & $\bullet$ \\
\hline & Caranx rhonchus & $\mathrm{p} 1-\mathrm{bt}$ & Mo & 2004 \\
\hline & Lichia amia & p2-ge & $\mathrm{Ma}$ & 2005 \\
\hline & Alectis alexandrinus & $\mathrm{p} 1-\mathrm{mc}$ & Mo & 2004 \\
\hline & Trachinotus ovatus & p2-ge & Ma & 2004 \\
\hline & Trachinotus teraia & $\mathrm{p} 1-\mathrm{bt}$ & Em & 2004 \\
\hline Carcharhinidae & Carcharhinus leucas & p2-pi & Mo & 2005 \\
\hline \multirow[t]{2}{*}{ Cichlidae } & Tilapia guineensis & he-de & Es & $\bullet$ \\
\hline & Sarotherodon melanotheron & he-ph & Es & $\bullet$ \\
\hline \multirow[t]{4}{*}{ Clupeidae } & Ethmalosa fimbriata & he-ph & Em & $\bullet$ \\
\hline & Ilisha africana & p1-zo & Em & $\bullet$ \\
\hline & Sardinella aurita & p1-zo & $\mathrm{Ma}$ & 2004 \\
\hline & Sardinella maderensis & p1-zo & ME & $\bullet$ \\
\hline \multirow[t]{2}{*}{ Cynoglossidae } & Cynoglossus monodi & $\mathrm{p} 1-\mathrm{bt}$ & Mo & $\bullet$ \\
\hline & Cynoglossus senegalensis & $\mathrm{p} 1-\mathrm{bt}$ & Em & $\bullet$ \\
\hline \multirow[t]{2}{*}{ Dasyatidae } & Dasyatis margarita & $\mathrm{p} 1-\mathrm{bt}$ & Em & $\bullet$ \\
\hline & Dasyatis margaritella & $\mathrm{p} 1-\mathrm{bt}$ & Em & $\bullet$ \\
\hline Drepaneidae & Drepane africana & p1-mc & ME & $\bullet$ \\
\hline Echeneidae & Echeneis naucrates & p1-zo & Mo & 2005 \\
\hline \multirow[t]{2}{*}{ Elopidae } & Elops lacerta & p2-pi & ME & $\bullet$ \\
\hline & Elops senegalensis & p2-pi & Ma & 2005 \\
\hline \multirow[t]{2}{*}{ Ephippidae } & Chaetodipterus goreensis & p1-mc & Mo & $\bullet$ \\
\hline & Chaetodipterus lippei & $\mathrm{p} 1-\mathrm{mc}$ & Ma & $\bullet$ \\
\hline Exocoetidae & Fodiator acutus & $\mathrm{p} 1-\mathrm{mc}$ & $\mathrm{Ma}$ & $\bullet$ \\
\hline \multirow[t]{2}{*}{ Gerreidae } & Eucinostomus melanopterus & $\mathrm{p} 1-\mathrm{mc}$ & ME & $\bullet$ \\
\hline & Gerres nigri & $\mathrm{p} 1-\mathrm{mc}$ & Es & $\bullet$ \\
\hline Gobiidae & Chonophorus lateristriga & $\mathrm{p} 1-\mathrm{bt}$ & Es & 2005 \\
\hline \multirow[t]{5}{*}{ Haemulidae } & Brachydeuterus auritus & $\mathrm{p} 1-\mathrm{mc}$ & ME & $\bullet$ \\
\hline & Pomadasys incisus & $\mathrm{p} 1-\mathrm{bt}$ & Ma & 2004 \\
\hline & Pomadasys jubelini & $\mathrm{p} 1-\mathrm{bt}$ & Em & $\bullet$ \\
\hline & Plectorhinchus macrolepis & p2-ge & Em & $\bullet$ \\
\hline & Pomadasys perotaei & $\mathrm{p} 1-\mathrm{bt}$ & Em & $\bullet$ \\
\hline Hemiramphidae & Hemiramphus brasiliensis & p2-ge & Em & $\bullet$ \\
\hline \multirow[t]{2}{*}{ Lutjanidae } & Lutjanus dentatus & p2-pi & Mo & 2005 \\
\hline & Lutjanus goreensis & p2-pi & Ma & $\bullet$ \\
\hline Monodactylidae & Monodactylus sebae & p2-ge & Es & $\bullet$ \\
\hline Moronidae & Dicentrarchus punctatus & p2-ge & Mo & 2007 \\
\hline \multirow[t]{6}{*}{ Mugilidae } & Liza dumerili & he-de & Em & $\bullet$ \\
\hline & Liza falcipinnis & he-de & Em & $\bullet$ \\
\hline & Liza grandisquamis & he-de & Em & $\bullet$ \\
\hline & Mugil bananensis & he-de & ME & $\bullet$ \\
\hline & Mugil cephalus & he-de & $\mathrm{ME}$ & $\bullet$ \\
\hline & Mugil curema & he-de & Em & $\bullet$ \\
\hline Myliobatidae & PteromyLaëus bovinus & p2-ge & Mo & 2005 \\
\hline Paralichthyidae & Citharichthys stampflii & p2-ge & Em & $\bullet$ \\
\hline
\end{tabular}




\begin{tabular}{lllll}
\hline Polynemidae & Polydactylus quadrifilis & $\mathrm{p} 2-\mathrm{pi}$ & $\mathrm{ME}$ \\
& Galeoides decadactylus & $\mathrm{p} 2-\mathrm{ge}$ & $\mathrm{ME}$ \\
Sciaenidae & Pseudotolithus brachygnathus & $\mathrm{p} 2-\mathrm{ge}$ & $\mathrm{ME}$ \\
& Pseudotolithus elongatus & $\mathrm{p} 2-\mathrm{ge}$ & $\mathrm{Em}$ \\
& Pseudotolithus senegalensis & $\mathrm{p} 2-\mathrm{ge}$ & $\mathrm{Ma}$ & \\
Scombridae & Scomberomorus tritor & $\mathrm{p} 2-\mathrm{pi}$ & $\mathrm{Ma}$ & \\
& Orchinopsis unicolor & $\mathrm{p} 2-\mathrm{pi}$ & $\mathrm{Mo}$ & \\
Serranidae & Epinephelus aeneus & $\mathrm{p} 2-\mathrm{pi}$ & $\mathrm{ME}$ & 2004 \\
Sparidae & Diplodus bellottii & $\mathrm{p} 1-\mathrm{bt}$ & $\mathrm{Mo}$ & 2004 \\
Sphyraenidae & Sphyraena guachancho & $\mathrm{p} 2-\mathrm{pi}$ & $\mathrm{ME}$ & 2004 \\
& Sphyraena afra & $\mathrm{p} 2-\mathrm{pi}$ & $\mathrm{ME}$ & 2004 \\
Syngnathidae & Hippocampus algiricus & $\mathrm{p} 1-\mathrm{bt}$ & $\mathrm{Ma}$ & \\
& Syngnathus pelagicus & $\mathrm{p} 1-\mathrm{bt}$ & $\mathrm{Ma}$ & \\
Synodontidae & Trachinocephalus myops & $\mathrm{p} 2-\mathrm{pi}$ & $\mathrm{Mo}$ & 2005 \\
Tetraodontidae & Ephippion guttifer & $\mathrm{p} 1-\mathrm{bt}$ & $\mathrm{ME}$ & \\
& Lagocephalus Laëvigatus & $\mathrm{p} 2-\mathrm{ge}$ & $\mathrm{Ma}$ & \\
& Sphoeroides spengleri & $\mathrm{p} 1-\mathrm{bt}$ & $\mathrm{Mo}$ & \\
& Ser &
\end{tabular}

Black Diamond $(\bullet)$ symbolized the 51 fish species inventoried in the creek before fishing ban. For each of the 22 newly recruited fish species, the year of its first occurrence in capture is mentioned. See Figure 3 for abbreviations.

\section{Discussion}

\subsection{Morpho-Functional Groups Composition}

The primary aim of this study was to develop a new functional classification of fish assemblages. The secondary aim was to assess the functional impact of the reserve throughout a multiple-scale functional guilds, allowing the reduction of biases related to unstable environment conditions and transience in trophic relationships. The study has been impaired by some limitations in our sampling efforts. Less than 50 species for which morphometric data had been recorded, were classified into our new functional guilds, while all the 72 species described in the system were included in the analysis based on the two previous classifications. This is due to the very low occurrence in the reserve of some marine species in particular, which are not captured during our sampling campaigns. However, the classified species represent more than $90 \%$ of the total biomass, and the sampling effort associated biases should have little effect on our results. The cutoff point of the dendrogram was arbitrary chosen, however, as found in Davenport and Bax (2004), the interpretability of the results based on the available ecological knowledge in the system may be used as a relevant criteria. Our results appear to classify fish species firstly in accordance with their trophic niche and food acquisition strategy and secondly with their habitat preferences. The present study allowed us to merge into four main guilds some insignificant functional groups issued from the previous classifications. Almost a half of total species clustered in the guild of demersal ichthyophagous, showing the dominance of predatory fishes in the assemblages, they are followed by benthopelagic fish species. Our results are very similar to those of Oribhabor and Ogbeibu (2012) in the Niger Delta (Nigeria), who also mentioned the dominance of fish assemblages by predatory fish distributed into two groups, the benthic feeders and benthopelagic fish.

Thus, algivorous / detritivorous guild included many mullets characterized by their fusiform body shapes and their small mouths and two species of the genus tilapia. The trophic status of mullets and that of tilapias are widely studied, however the conclusions remain controversial. Mullets have been fundamentally known, either as grazers, or detritus feeders, even if they may include detritus and meiofauna in their diets (Paterson \& Whitfield, 1997; Mbande, Froneman, \& Whitfield, 2004; Lin, Kao, \& Wang, 2007). Tilapias have also been described as detritivores in the Zambesi River by Winemiller and Kelso-Winemiller (2003). However, according to Sakdullah and Tsuchiya (2009), tilapias may feed by filtering suspended particles (plankton, detritus and macroalgae). Oribhabor and Ogbeibu (2012), have described the species of both families (except L. dumerili and S. melanotheron) as mud feeders. It seems that both taxa showed a high plasticity in their diets in relationships with food availability. 
Table 4. Comparison between functional classification approaches based respectively on stable isotope (Faye et al., 2011), gut content (Faye et al., 2012) and morpho-functional (the present study) analysis

\begin{tabular}{|c|c|c|c|}
\hline \multirow{19}{*}{ 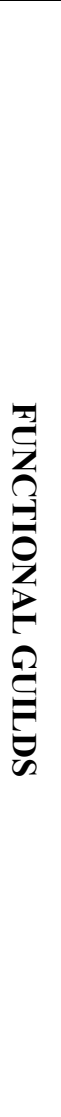 } & \multicolumn{3}{|c|}{ FUNCTIONAL APPROACHES } \\
\hline & $\begin{array}{l}\text { Stable isotopes analysis } \\
\text { (Faye et al., 2011) }\end{array}$ & $\begin{array}{l}\text { Functional morphology (Present } \\
\text { study) }\end{array}$ & $\begin{array}{l}\text { Gut contents analysis } \\
\text { (Faye et al., 2012) }\end{array}$ \\
\hline & C 1-INT and C2 BAF & Algivorous / Detritivorous & Detritivorous \\
\hline & Sarotherodon melanotheron & S. melanotheron & T. guineensis \\
\hline & $(\mathrm{C} 1)$ & Tilapia guineensis & Ethmalosa fimbriata \\
\hline & Mullets (C2) & Majority of Mullets & \\
\hline & C 2-PAF & Benthopelagic fish & Benthic invert. feeders \\
\hline & E. fimbriata & E. fimbriata & E. melanopterus \\
\hline & & Eucinostomus melanopterus & Gerres nigri \\
\hline & Dasyatis $s p$ & Sardinella maderensis & Pomadasys perotaei \\
\hline & & Elops lacerta & S. maderensis \\
\hline & C2-INT & Demersal and ichthyophagous fish & Macrocarnivores \\
\hline & Lutjanus goreensis & P. perotaei & \\
\hline & G. nigri & Epinephelus aenus & \\
\hline & E. melanopterus & G. nigri & L. goreensis \\
\hline & Monodactylus sebae & L. goreensis & \\
\hline & S. maderensis & Liza dumeriili & \\
\hline & C 3 & Pseudotholitus elongatus & \\
\hline & E. lacerta & & E. lacerta \\
\hline
\end{tabular}

For the purpose of comparison, only the more symbolic species are quoted. C2-BAF - Secondary consumer-Benthic affinity feeders, C2-INT- Secondary consumer-intermediate; C2 PAF-Secondary consumer-Pelagic affinity feeders; C3-Tertiary consumers.

The benthopelagic guild included medium-size pelagic and benthic fish of different trophic status and taxonomic identity. Both of the adult and juvenile stages of E. fimbrita clustered in this guild. The consideration of the two ecophases of this species in the present study is dictated by its particular ecology, E. fimbriata is a gregarious species, the more abundant one in the Sine-Saloum estuary, where it constitutes important shoaling alternatively dominated, either by adult, or juvenile forms depending on the seasons. Our results allowed to discriminate the two gerreids (E. melanopterus and G. nigri), which figure among the more occurring species in the Bamboung creek. Both species are known as benthic feeders, however, in the present analysis, they clustered in different functional guilds. Eucinostomus melanopterus belonged to the benthopelagic fish guild, while G. nigri clustered with demersal and ichthyophagous fish species. These conclusions corroborate those of Faye et al. (2012), based on gut content analysis, whom found that even if both species have a benthic affinity, their niche diet did not overlap ( 0.45 following the Horn-Morisita dissimilarity, and the threshold is set at 0.4). Eucinostomus melanopterus, exploited more benthic and supra-benthic or pelagic crustacean prey, while G. nigri mainly fed on benthic bivalve mollusks, justifying its classification in the new clustering. The occurrence of E. lacerta in this guild is quite surprising as this species is known to be a strict pelagic piscivore, feeding mainly on small clupeids (Fagade \& Olaniyan, 1973). Its occurrence in this guild may be related to its pelagic character, morphologically symbolized by its up-turned mouth and its long gill rakers suggesting that it may exploit other prey than fishes. This assumption is consistent, because all specimen met in the creek are relatively young and should not shift to their adult diet.

The group of zoobenthos feeders included mainly large, fast moving species of Carangidae characterized by their laterally compressed bodies. These species are often represented in marginal ecosystems (estuaries and reefs) by sub-adults, which used these areas as growing sites before migrating in deeper habitats (Adams et al., 2006). As earlier described in Longhurst (1957) and more recently in Fishbase (Froese \& Pauly, 2010), the diet of these species is mainly composed by nektonic prey (crustaceans and small fish). According to Blaber (1997), the 
juvenile of E. fimbriata, gerreids and cichlids represented the main prey of carangids in estuaries. The two other members of this guild Chaetodipterus lippei and Monodactylus sebae are relatively small-size species. Chaetodipterus lippei has been classified by the RAP Unit Research as a moluscivorous species, however according to Longhurst (1957) this species may include in its diet other benthic invertebrates as polychaetes and algae. The trophic status of M. sebae, as reviewed by Faye et al. (2012) is characterized by a wide trophic niche including more than eight functional prey categories. The last functional guild that of demersal and ichthyophagous fish included benthic fusiform fishes. Species in this group feed on other fishes and invertebrates, while the occurrence of $L$. dumerili (mullet) in this guild requires more emphasis. This species has previously been described by many authors (Heymans \& Baird, 1995; Paterson \& Withfield, 1997) as a benthic microalgae feeder. Based on our own measurements, $L$. dumerili has the lowest intestine relative length (1.6) among mullets, the other species of the ratios are close to four. Our results are in agreement with those found in Dankwa, Blay Jr., and Yankson (2005), in the estuarine complex of the Gulf of Guinea, where the mean relative intestine length of $L$. dumerili was close to 1.7, while that of the other mullets reached 4.5. In the light of the morphometric paradigm defined in Sibbing and Nagelkerke (2001), a short intestine characterizes a specialization in a carnivorous diet. In correlation with its short gut, Dankwa et al. (2005) found that $L$. dumerili fed preferentially on zooplankton, polychaetes and diatoms, even if it may include in its diet a wide proportion of coarser sand particles rich in animal material. In another West African estuary (Benin), L. dumerili has been described as an omnivorous species by Adite and Winemiller (1997), from a study based on gut content analysis. More recently, stable isotope analysis run with samples collected in the BPA, revealed that $L$. dumerilli appears to be a benthic feeder (Faye et al., 2011). The other species of this guild are notoriously known either, as benthic invertebrate feeders (Haemulids, Batrachoidids, Ephippids), or generalist predators (Ariids, Lutjanids) and strict piscivores (Sciaenids, Serranids, Sphyraenids). Details relative to the trophic status of these species may be found in Diouf (1996); in Blaber (1997) and more recently in Faye et al. (2012). A synthesis of the present classification and its comparison with the previous one based, either on stable isotope or gut content analysis, operated on samples collated from the same creek is shown in Table 4.

\subsection{Functional Modifications in Fish Assemblage Structure}

The present study highlights three key issues: firstly, fishing ban has a rapid (from 1 to 3 years) effect on fish assemblages composition, however, the rate of changes may be variable from a given functional group to another; Secondly, it has been observed a reduction in total fish biomass in the system from 2003 to 2007 combined to a high inter-annual variability. Thirdly, the responses of some guilds are negatively synchronized.

\subsubsection{Response Time}

After one year of protection, the proportion of detritivorous fish collapsed, while that of generalist predators rose up. A similar trend has been observed between the herbivorous and the piscivorous species after three years of protection. The classification based on morphometric characteristic highlights these observations by reducing the fish assemblage's complexity into two major guilds, which show very close similarity in their dynamics but in opposite trends. The delay of fish assemblage response observed in the present study is in conformity to those previously reported in the literature. According to a meta-analysis by (Russ, 2001), the biomass of top predator fish in marine reserves may increase by a factor of 1 to 13 during three years of protection.

\subsubsection{Total Biomass Evolution}

The observed reduction in fish total biomass is far from being an unusual observation in marine reserve dynamics, and may be explained by a bulk of factors. The catfish's raw data collected in 2007, for example, has been smoothed, consecutively to an over yield seine hauls. Nevertheless, the observed decreasing trend in total fish biomass has been observed by Sow and Guillard (2010) based on hydro-acoustic estimation (Figure 5). According to these authors, the key modifications affecting the system occurred in 2007. Elsewhere, the specific biomass value in an ecosystem remains difficult to estimate, due to imprecisions in protocols and spatial and temporal dynamics of species. However, despite these issues the observed specific biomass values remained in the range of those reported in (Blaber, 1997) for the West African estuaries (400 to $15000 \mathrm{~kg} \cdot \mathrm{km}^{-2}$ ). More recently, Baran (2000), had reviewed these values, and gave more accurate estimations between 0 and $4100 \mathrm{~kg} \cdot \mathrm{km}^{-2}$.

The increasing proportion of top predatory fish has often resulted in an intensification of biotic interactions (competition and predation), owing the intensity dependence processes and food limitation (Rakitin \& Kramer, 1996; Graham et al., 2003). Such a diminution in the total fish biomass is commonly observed in many reserves. MacClanahan and Kaunda-Arara (1996), for example, reported a decrease of 25 to $50 \%$ in total fish biomass in Mombasa marine reserve (Kenya), according to these authors three main factors may explain this observation: poor recruitment, slow regeneration (low rates of growth and survival) of herbivore communities resulting from 
the intensive interspecific competition with unfished benthic invertebrate grazers, failure in surveillance and night poaching. Similar trends have also been reported by Wantiez, Thollot, and Kulbicki (1997) in Caledonian marine reserves, and were attributed to the influence of major and cyclic climatic events as El-Ninos (Wantiez, 2002). However, in the Bamboung Protected Area, environmental conditions remained quite stable throughout the year, more a preliminary multivariate analysis (Unpublished work, 2008) has shown that there were no significant relationships between fish assemblage structure and environmental variables. Nevertheless, the BPA is naturally an open system interacting indirectly with the ocean through the Sine-Saloum river main channel and with other upstream major creeks, where powerful environmental forces may operate.

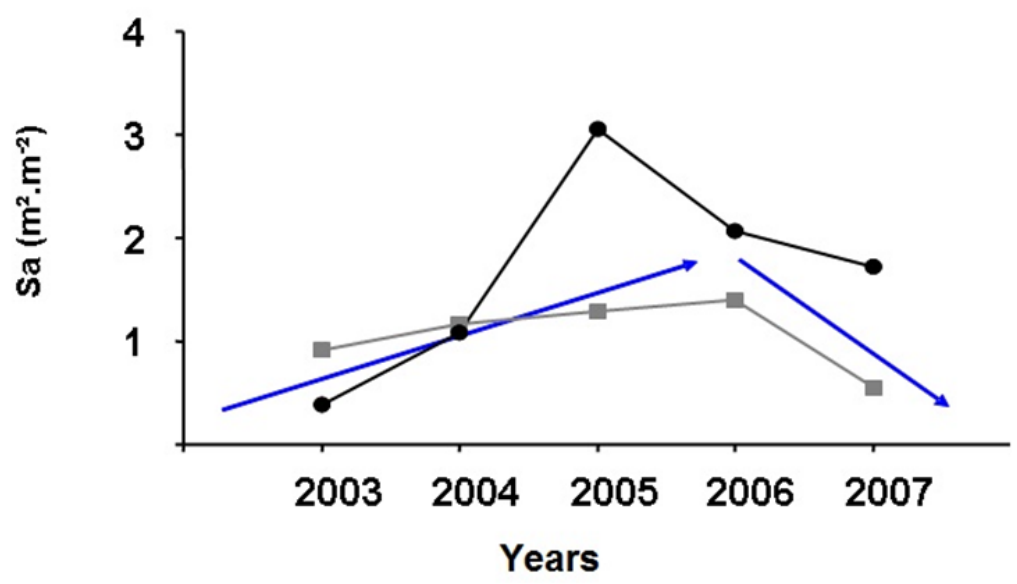

Figure 5. Fish assemblages average annual biomass evolution between 2003 and 2007 estimated using the hydro acoustic method (Sow \& Guillard, 2010). The black spots and grey squares indicated respectively the recorded values, through transects in upstream and downstream directions, and blue arrows the average biomass

\subsubsection{Functional Guild Differential Rate of Responses}

We hypothesized that the loss of fish biomass in lower food web levels may be linked to the predation intensity effects, reinforced by the narrowness of the creek, and spillover. Similar hypothesis had been suggested by many other authors. Colléter, Gascuel, Ecoutin, and Tito de Morais (2012), for example, have found a 2.5 fold increase in predatory fish biomass, while that of their prey decreased by a factor of 1.7. They attempted to link these modifications mainly to environmental effects combined to other factors as the predation pressure reinforced by the probable occurrence of cascading mechanism and the variability in the recruitment of forage fish, in particular, E. fimbriata. Thus, the stock of E. fimbriata, the main phytophagous species in the systems, may be severely depleted by the predation pressure on other benthopelagic piscivorous species as Elopids or Clupeids (Ilisha africana). However, even if the phenomenon of intraguild predation may occur in the system, its impact should be low, as many piscivores clustering in this group are, either of relatively small size, or only represented by juvenile and subadult specimen. In contrast, a high predation impacts of large piscivores clustering in the guild of demersal fishes may be suggested to support the hypothesis of biotic regulation processes in the system. The occurrence of such phenomenon, in marine reserves has been documented by many authors (Salomon, Waller, Mcllhagga, Yung, \& Walters, 2002; Hereu, Zabala, Linares, \& Sala, 2005; Baskett, Micheli, \& Levin, 2007). According to Micheli and Halpern (2005), biotic interactions remain the key regulating mechanisms in marine reserves, and predation processes constitute the main factors of biomass loss in small pelagic fish (Thébault \& Loreau, 2005; Gamble \& Link, 2009). Our second major hypothesis is relative to the effect of biomass export out of the reserve, ecologically known as spillover effect (Russ \& Alcala, 1996; Russ, Alcala, \& Maypa, 2003). According to Brochier, Ecoutin, Tito de Morais, Kaplan, \& Laë (2013), one third of biomass produced in the reserve are exported mainly by the natural diffusion through the adjacent creek boundaries of eggs and juveniles, combined to seasonal migrations and sea relocations of large predators.

Elsewhere, algivorous and detritivorous fish have shown a remarkable decrease in their proportions. However, most of the species (mullets) composing this guild have a marine affinity, and are temporally present in the estuary. The second members are tilapia species, which are less susceptible to be captured by the seine net, as they use the bordering mangrove trees as shelters. In contrast, the benthic invertebrate feeders responded positively to the 
protected status. Seemingly, if our hypothesis of predation mediated-regulation is maintained, their positive trends may be explained by the fact that the species in this guild (juveniles and subadults of carangid fish) were not severely affected by the predation due to their relatively large size and their laterally compressed body shape.

The third approach relative to fish species life-history traits allowed to reach similar conclusions than the two precedent ones, however, in a managerial perspective, it may have a particular interest in the definition of strategic plans to protect mobile species through the establishment of temporal corridors. Broadly, the BPA establishment did not radically change the structure of the fish assemblages following this dimension, which remain constantly dominated by marine species in a broader sense. However, after fishing ban it has been found that estuarine species of marine origins (Em) were being progressively supplanted by marine estuarine species (ME). In this category, we found the threadfins (Polydactylus quadrifilis, Galeoides decadactylus, the croaker (Pseudotolithus brachygnathus), the grouper (E. aeneus) and the barracudas (Sphyraena afra, Sphyraena guachancho). Many other marine species as the scombrids and the snapper (L. goreensis) are also frequently captured in the creek. Their occurrence may be explained by the utilization of the reserve and its boarding mangroves as feeding and resting areas for adults and as nurseries for juvenile forms.

\subsubsection{Functional Redundancy}

The annual functional richness of 38 species is theoretically the equivalence of the annual taxonomic richness, meaning the number of species entering or found in the reserve in a year. However, a little gap may be found in comparison with values calculated from the original data, due to the incompleteness of samples used to build our morpho-functional guilds. By minimizing this gap, this diversity represents the half of the total number of species inventoried in the creek, suggesting a high level of species turnover. The functional redundancy index showed a highest value (10) in 2003 and then decreased gradually. Such a trend should theoretically be explained by two hypothesis. Firstly, a reduction in the taxonomic species diversity may occur in relationship with species removal. Such a scenario has to be discarded owing to the real observed trend corresponding to an increase of over $40 \%$ in species richness. The second hypothesis is relative to the introduction of new functions in the systems, simultaneously with species recruitment. This hypothesis may be defended by interpreting the FRI model structure. Likely, each of the four new guilds were unless represented by one species before the effective fishing ban. Globally the number of functions in the systems remained the same. But, instead of having the majority of species grouped into one or two functional units (meaning a high redundancy), they are dispatched among a wide spectra. The weight of each functional group rose up, leading to an overall niche diversification. The functional diversity parameter has shown a high sensitivity to species temporal and spatial distribution in relationship with environmental variability and climatic variations (Villéger, Miranda, Hernandez, \& Mouillot, 2010; Wiedmann et al., 2014). In our studied systems, there are no longer heavy contrasted environmental conditions between the major sites, that's why a spatial comparison was not done. Besides the effect of the protection, other lateral factors as discussed above may explain the FRI fluctuations.

\section{Conclusion}

Globally, it has been found that the three approaches are complementary. However, the morphology-based classification resulted in more significant units and allowed a more synthetic analysis of the evolution compared to those issued from gut content or fish life-history traits analysis. However, these latter may play an important role in decision making relative to the mobile species protection. Our results reinforce the recommendations issued from many studies addressing the usefulness of a multiple approach method in marine reserves monitoring. The protection status resulted in a deep modification in fish assemblage functional structure. However, the current state of the evolution did not necessary presage the future dynamic of the systems. Based on the experiences and practices in other MPA through the world, a continual monitoring program is recommended, during at least a decade to track the advent of the stabilization phase in fish assemblages and in the whole system.

\section{Acknowledgements}

The Bamboung Protected Area project has been initially funded by the French Fund for Global Environment. I'm grateful to the "Département Soutien et Formation" of the Research Institute for Development (IRD, France) for funding my doctoral research fellowship. Internship and data sharing were the fruit of the collaboration between the precedent Institute and the Aquatic Living Resources Unit Research of the Institute of Fisheries and Aquaculture (IUPA) and the Department of Animal Biology of Dakar University (UCAD). Researches were performed in the IRD / RAP (Adaptive Response of fish assemblages to the environment Pressure) Unit Research program and laboratories in Bel-Air (Senegal). Finally, I'm thinking the crew on board (fishermen and the technical staff) in the Diassanga catamaran for monitoring campaigns and sample collection. 


\section{References}

Abesamis, R. A., Russ, G. A., \& Alcala, A .C. (2006). Gradients of abundance of fish across no-take marine reserve boundaries: evidence from Philippine coral reefs. Aquatic Conserv: Mar. Freshw. Ecosyst., 16, 349-371. http://dx.doi.org/10.1002/aqc.730

Adams, A. J., Dahlgren, C. P., Kellison, G. T., Kendall, M. S., Layman, C. A., Ley, J. A., ... Serafy, J.E. (2006). Nursery function of tropical back-reef systems. Mar Ecol: Prog Ser, 318, 287-310.

Adams, S. M., Hill, W. R., Peterson, M. J., Ryon, M. G., Smith, J. G., \& Stewart, A. J. (2002). Assessing recovery in a stream ecosystem: applying multiple chemical and biological endpoints. Ecol. Applic., 12, 1510-1527. http://dx.doi.org/10.1890/1051-0761(2002)012[1510:ARIASE]2.0.CO;2

Adite, A., \& Winemiller, K. O. (1997). Trophic ecology and ecomorphology of fish assemblages in coastal lakes of Benin. Ecoscience, 4, 6-23.

Albaret, J-J. (1994). Les poissons: biologie et peuplements. In J. R. Durand, P. Dufour, D. Guiral, \& S. G. Zabi (Eds), Environnement et ressources aquatiques de Côte d'Ivoire, Tome II (pp. 239-279). Les milieux lagunaires, Editions ORSTOM, Paris.

Albaret, J-J., Simier, M., Famara, Darboe. F. S., Ecoutin, J-M., \& Tito de Morais, L. (2004). Fish diversity and distribution in the Gambia Estuary, West Africa, in relation to environmental variables. Aquat Living Resour, 17, 35-46. http://dx.doi.org/10.1051/alr:2004001

Baran, E. (2000). Biodiversity of estuarine fish faunas in West Africa. Naga. The ICLARM Quaterly, 23, 4-9.

Baskett, M. L., Micheli, F., \& Levin, S. A. (2007). Designing marine reserves for interacting species: Insights from theory. Biol. Cons., 137(2), 163-179. http://dx.doi.org/10.1016/j.biocon.2007.02.013

Begg, G. A., Mapstone, B. D., Williams, A. J., Adams, S., Davies, C. R., \& Lou, D. C. (2005). Multivariate life-history indices of exploited coral reef fish populations used to measure the performance of no-take zones in a marine protected area. Can. J. Fish. Aquat. Sci., 62, 679-692. http://dx.doi.org/10.1139/F04-237

Blaber, S. J. M. (1997). Fish and fisheries at tropical estuaries. In Chapman \& Hall (Eds), London, UK, 388 p.

Bousso, T. (1996). La pêche artisanale dans l'estuaire du Sine-Saloum (Sénégal). Approches typologiques des systèmes d'exploitation. Thèse de Doctorat, Université Montpellier II, Montpellier, France. 293 p.

Bouton, N., Van, O. N., \& Witte, F. (1998). Feeding performance of Lake Victoria rock cichlids: testing predictions from morphology. J. Fish Biol., 53(sup. issue), 118-127. http://dx.doi.org/10.1111/j.1095-8649. 1998.tb01022.x

Brochier, T., Ecoutin, J. M., Tito de Morais, L., Kaplan, D., \& Laë, R. (2013). A multi-agent ecosystem model for studying changes in a tropical estuarine fish assemblage within a marine protected area. Aquat. Living Resour., 26, 147-158. http://dx.doi.org/10.1051/alr/2012028

Bulman, C., Althaus, F., He, X., Bax, N. J., \& Williams, A. (2001). Diets and trophic guilds of demersal fishes of the south-eastern Australian shelf. Aust. J. Mar. Freshwater Res., 52, 537-548. http://dx.doi.org/10.1071/ MF99152

Cardinale, B. J., Srivastava, D. S., Duffy, J. E., Wright, J. P., Downing, A. L., Sankaran, M., \& Jouseau, C. (2006). Effects of biodiversity on the functioning of trophic groups and ecosystems. Nature, 443, 989-992. http://dx.doi.org/10.1038/nature05202

Charles-Dominique, E. (1989). Catch efficiencies of purse and beach seines in Ivory Coast Lagoons. Fish. Bull., 87, 911-921.

Cohen, J. E., Pimm, S. L., Yodzis, P., \& Saldana, J. (1993). Body size of an animal predators and animal prey in food webs. J. Anim. Ecol., 62, 67-78. URL: http://www.jstor.org/stable/5483

Coll, M., Santojanni, A., Palomera, I., Tudela, S., \& Ameri, E. (2007). An ecological model of the Northern and central sea: analysis of ecosystem structure and fishing impacts. J. Mar. Sys., 67, 119-154. http://dx.doi.org/ 10.1016/j.jmarsys.2006.10.002

Colléter, M., Gascuel, D., Ecoutin, J. M., \& Tito de Morais, L. (2012). Modelling trophic flows in ecosystems to assess the efficiency of marine protected area (MPA), a case study on the coast of Senegal. Ecol. Modell., 232, 1-13. http://dx.doi.org/10.1016/j.ecolmodel.2012.01.019 
Cury, P. M., Shannon, L. J., Roux, J. P., Daskalov, G. M., Jarre, A., Moloney, C. L., \& Pauly, D. (2005). Trophodynamic indicators for an ecosystem approach to fisheries. ICES J. Mar. Sci. 62, 430-442. http://dx.doi.org/10.1016/j.icesjms.2004.12.006

Cury, P., Shin, Y-J., Planque, B., Durant, J. M., Fromentin, J-M., Kramer-Schadt, S., Travers, M., ... Grimm, V. (2008). Ecosystem oceanography for global change in fisheries. Trends Ecol Evol, 23, 338-346. http://dx.doi.org/10.1016/j.tree.2008.02.005

Dankwa, H. R, Blay Jr., J., \& Yankson, K. (2005). Food and Feeding habits of Grey mullets (Pisces: Mugilidae) in two estuaries in Ghana. WAJAE 8, 62-80. http://dx.doi.org/10.4314/wajae.v8i1.45786

Davenport, S. R., \& Bax, N. J. (2002). A trophic study of a marine ecosystem of Southeastern Australia using stable isotopes of carbon and nitrogen. Can. J. Fish. Aquat. Sci. 59, 514-530. http://dx.doi.org/10.1139/ f02-031

Diouf, P. S. (1996). Les peuplements de poissons des milieux estuariens de l'Afrique de l'ouest: l'exemple de l'estuaire hyperhalin du Sine-Saloum, volume 156. ORSTOM, Paris, 267 pp. Thèse de doctorat, Université Montpellier II, Montpellier. http://www.bondy.ird.fr/pleins_textes/pleins_textes_7/TDM_7/010008130.pdf

Dumay, O., Tari, P. S., Tomasini, J. A., \& Mouillot, D. (2004). Functional groups of lagoon fish species in Languedoc Roussillon, southern France. J. Fish Biol., 64, 1-14. http://dx.doi.org/10.1111/j.1095-8649. 2004.00365.x

Ecoutin, J-M., Simier, M., Albaret, J-J., Laë, R., \& Tito de Morais, L. (2010). Changes over a decade in fish assemblages exposed to both environmental and fishing constraints in the Sine Saloum estuary (Senegal). Estuarine, Coastal Shelf Sci. 87, 284-292. http://dx.doi.org/10.1016/j.ecss.2010.01.009

Elliott, M., Whitfield, A. K., Potter, I. C., Blaber, S. J. M., Cyrus, D. P., Nordlie, F. G., \& Harrison, T. D. (2007). The guild approach to categorizing estuarine fish assemblages: a global review. Journal compilation Blackwell Publishing Ltd, Fish Fish, 8, 241-268.

Evans, R. D., \& Russ, G. R. (2004). Larger biomass of targeted reef fish in no-take marine reserves on the Great Barier Reef, Australia. Aquat Conserv, 4, 505-519. http://dx.doi.org/10.1002/aqc.631

Fagade, S. O., \& Olaniyan, C. I. (1972). The biology of the West African shad Ethmalosa fimbriata (Bodwich) in the Lagos lagoon, Nigeria. J. Fish Biol., 4, 519-533.

Faye, D., Le Loc'h, F., Thiaw, O. T., \& Tito de Morais, L. (2012). Mechanisms of food partitioning and ecomorphological correlates in ten fish species from a tropical estuarine Marine Protected Area (Bamboung, Senegal, Africa). Afr J Agr Res, 7, 443-455. http://dx.doi.org/10.5897/AJAR11.1088

Faye, D., Tito de Morais, L., Raffray, J., Sadio, O., Thiaw, O. T., \& Le Loc'h, F. (2011). Structure and seasonal variability of fish food webs in an estuarine tropical marine protected area (Senegal): Evidence from stable isotope analysis. Estuarine, Coastal Shelf Sci., 92, 607-617. http://dx.doi.org/10.1016/j.ecss.2011.02.017

Floeter, S. R., Halpern, B. S., \& Ferreira, C. E. L. (2006). Effects of fishing and protection on Brazilian reef fishes. Biol. Cons., 128, 391-402. http://dx.doi.org/10.1016/j.ecss.2011.02.017

Froese, R., \& Pauly, D. (2009). FishBase, World Wide Web electronic publication. www.fishbase.org.

Gamble, R. J., \& Link, J. S. (2009). Analyzing the tradeoffs among ecological and fishing effects on an example fish community: A multispecies (fisheries) production model. Ecol. Modell., 220, 2570-2582. http://dx.doi.org/10.1016/j.ecolmodel.2009.06.022

Gascuel, D., Laurans, M., Sidibé, A., \& Barry, M. D. (2002). Stock diagnosis and abundance trends for demersal resources in the countries of the CSRP. International Symposium Act, Dakar, 205-222.

Gatz, A. J. (1979). Community organization in fishes as indicated by morphological features. Ecology, 60, 711-718.

Gell, F. R., \& Roberts, C. M. (2003). Benefits beyond boundaries: the fishery effects of marine reserves. Trends Ecol. Evolut., 18, 448-455. http://dx.doi.org/10.1016/S0169-5347(03)00189-7

Hereu, B., Zabala, M., Linares, C., \& Sala, E. (2005). The effects of predator abundance and habitat structural complexity on survival of juvenile sea urchins. Mar. Biol., 146, 293-299. http://dx.doi.org/10.1007/s00227004-1439-y

Heymans, J. J., \& Baird, D. (1995). Energy flow model of the Kromme estuary, St Francis Bay, South Africa. Estuarine, Coastal Shelf Sci., 41, 39-59. http://dx.doi.org/10.1006/ecss.1995.0052 
Hoe, A. S., \& Bellwood, D. R. (2009). Limited Functional Redundancy in a High Diversity System: Single Species Dominates Key Ecological Process on Coral Reefs. Ecosystems, 12, 1316-1328. http://dx.doi.org/10.1007/ s10021-009-9291-z

Hulot, F. D., Lacroix, G., Lescher-Moutoué, F., \& Loreau, M. (2000). Functional diversity governs ecosystem response to nutrient enrichment. Nature, 405, 340-344. Http://dx.doi.org/10.1038/35012591

Jackson, G., \& Jones, G.K. (1999). Spatial and temporal variation in nearshore fish and macroinvertebrate assemblage from a temperate Australian estuary over a decade. Mar Ecol: Prog Ser, 182, 253-268.

Jennings, S., \& Mackinson, S. (2003). Abundance-body mass relationships in size-structured food webs. Ecol. Lett., 6, 971-974. http://dx.doi.org/10.1046/j.1461-0248.2003.00529.x

Jennings, S., Pinnegar, J. K., Polunin, N. V. C., \& Boon, T. W. (2001). Weak cross-species relationships between body size and trophic level belie powerful size-based trophic structuring in fish communities. J. Anim. Ecol. 70, 934-944. http://dx.doi.org/10.1046/j.0021-8790.2001.00552.x

Kulbicki, M. (2007). Du macroscope au microscope. Les poisons coralliens du Pacifique comme modèle. 180 p. Diplôme d'Habilitation à Diriger des Recherches, Université de Perpignan, Perpignan, France.

Laurans, M., Gascuel, D. Chassot, E., \& Thiam, D. (2004). Changes in the trophic structure of fish demersal communities in West Africa in the three last decades. Aquat. Living Resour., 17, 163-173. http://dx.doi.org/10.1051/alr:2004023

Lin, H- J., Kao, W-Y., \& Wang, Y-T. (2007). Analysis of stomach contents and stable isotopes reveal food sources of estuarine detritivores fish in tropical / subtropical Taiwan. Estuarine, Coastal Shelf Sci., 73, 527-537. http://dx.doi.org/10.1016/j.ecss.2007.02.013

Longhurst, A. R. (1957). The food of the demersal fish of a West African estuary. J. Anim. Ecol., 26 (2), 369-387.

Loreau, M. (2000). Biodiversity and ecosystem functioning: recent theoretical advances. Oikos, 91, 3-17. http://dx.doi.org/10.1034/j.1600-0706.2000.910101.x

Loreau, M., \& Hector, A. (2001). Partitioning selection and complementarity in biodiversity experiments. Letters to Nature, 412, 72-76. http://dx.doi.org/10.1038/35083573

Mangel, M. (2000). Irreducible uncertainties, sustainable fisheries and marine reserves. Evol. Ecol. Resear., 2, 547-557.

Mbande, S., Froneman, P. W., \& Whitfield, A. K. (2004). The primary carbon sources utilised by fishes in the Mngazi and Mngazana estuaries, South Africa: a preliminary assessment. Afr. J. Aquat. Sci., 29, 195-204.

McClanahan, T. R., \& Kaunda-Arara, B. (1996). Fisheries recovery in a coral-reef marine park and its effect on the adjacent fishery. Conserv. Biol., 10, 1187-1199. Retrieved from http://www.jstor.org/stable/2387154

Micheli, F., \& Halpern, B. S. (2005). Low functional redundancy in coastal marine assemblages. Ecol. Lett., 8 , 391-400. 10.1111/j.1461-0248.2005.00731.x

Micheli, F., Halpern, B. S., Botsford, L. W., \& Warner, R. R. (2004). Trajectories and correlates of community change in No-Take Marine Reserves. Ecol. App., 14, 1709-1723. http://dx.doi.org/10.1890/03-5260

Mouillot, D., Dumay, O., \& Tomasini, J. A. (2007). Limiting similarity, niche filtering and functional diversity in coastal lagoon fish communities. Estuarine, Coastal Shelf Sci., 71, 443-456. http://dx.doi.org/10.1016/ j.ecss.2006.08.022

Naeem, S., \& Li, S. (1997). Biodiversity enhances ecosystem reliability. Nature, 390, 507-509.

Neubert, M. G., Blumenshine S. C., Duplisea, D. E., Jonsson, T., \& Rashleigh, B. (2000). Body size and food web structure: testing the equiprobability assumption of the cascade model. Oecologia, 123, 241-251.

Oribhabor, B. J., Ogbeibu, A. E. (2012). The food and feeding habits of fish species assemblages in Niger Delta Mangrove Creek, Nigeria. J Fish Aquat Sci, 7, 134-149. http://dx.doi.org/10392/jfas.2012.134.149

Panfili, J., Mbow, A., Durand, J-D., Diop, K., Diouf, K., Thior, D., .. \& Laë, R. (2004). Influence of salinity on the life-history traits of the West African black-chinned tilapia (Sarotherodon melanotheron): Comparison between the Gambia and Saloum estuaries. Aquat. Living Resour., 17, 65-74. http://dx.doi.org/10.1051/alr:2004002 
Paterson, A. W., \& Withfield, A. K. (1997). A stable carbon isotope study of the food-web in a freshwater-deprived South African Estuary, with particular emphasis on the ichthyofauna. Estuarine, Coastal Shelf Sci., 45, 705-715. http://dx.doi.org/10.1006/ecss.1997.0243

Petchey, O. L., Gaston, K. J., (2002). Functional diversity (FD), species richness and community composition. Ecol. Lett., 5, 402-411. http://dx.doi.org/10.1046/j.1461-0248.2002.00339.x

Petchey, O. L., \& Gaston, K. J. (2006). Functional diversity: back to basics and looking forward. Ecol. Lett., 9 , 741-758. http://dx.doi.org/10.1111/j.1461-0248.2006.00924.x

Petchey, O. L., Hector, A., Gaston, K. J. (2004). How do different measures of functional diversity perform? Ecology, 85, 847-857.

Pikitch, E. K., Santora, C., Babcock, E. A., Bakun, A., Bonfil, R., Conover, D. O., ... \& Sainsbury, K. J. (2004). Ecosystem-based fisheries management. Science, 35, 346-447.

Power, M. (1999). Recovery in aquatic ecosystems: an overview of knowledge and needs. J. Aquat. Ecosyst. Stress Recovery, 6, 253-257. http://dx.doi.org/10.1111/10.1023/A:1009991620319

Rakitin, A., \& Kramer, D. L. (1996). Effect of a marine reserve on the distribution of coral reef fishes in Barbados. Mar Ecol: Prog Ser, 131, 97-113.

Rosenfeld, J. S. (2002). Functional redundancy in ecology and conservation. Oikos, 98, 156-162.

Russ, G. R. (2001). Marine reserves as reef fisheries management tools: yet another Review. In P. F. Sale (Eds), Coral Reef Fishes (pp. 421-443). Academic Press.

Russ, G. R., \& Alcala, A. C. (1996). Do marine reserves export adult fish biomass? Evidence from Apo Island, central Philippines. Mar Ecol: Prog Ser, 132, 1-9.

Russ, G. R., Alcala, A. C., \& Maypa, A. P. (2003). Spillover from marine reserves: the case of Naso vlamingii at Apo Island, the Philippines. Mar Ecol: Prog Ser, 264, 15-20.

Sakdullah, A., \& Tsuchiya, M. (2009). The origin of particulate organic matter and diet of tilapia from an estuarine ecosystem subjected to domestic wastewater discharge: fatty acid analysis approach. Aquat. Ecol., 43, 577-589. http://dx.doi.org/10.1007/s10452-008-9195-6

Salomon, A. K., Waller, N. P., McIlhagga, C., Yung, R. L., \& Walters, C. (2002). Modelling the trophic effects of marine protected area zoning policies: A case study. Aquat. Ecol., 36, 85-95.

Scharf, F., Juanes, F., Rountree, R. A. (2000). Predator size - prey size relationships of marine fish predators: interspecific variation and effects of ontogeny and body size on trophic-niche breadth. Mar Ecol: Prog Ser, $208,229-248$.

Sibbing, F. A., \& Nagelkerke, L. A. J. (2001). Resource partitioning by Lake Tana barbs predicted from fish morphometrics and prey characteristics. Rev Fish Biol Fisher, 10, 393-437. http://dx.doi.org/10.1023/ A:1012270422092

Sih, A., \& Christensen, B. (2000). Optimal diet theory: when does it work, and when and why does it fail? Anim Behav, 2001, 61, 379-390 http://dx.doi.org/10.1006/anbe.2000.1592

Simier, M., Blanc, L., Aliaume, C., Diouf, P. S., \& Albaret, J-J. (2004). Spatial and temporal structure of fish assemblages in an "inverse estuary", the Sine-Saloum system (Senegal). Estuarine, Coastal Shelf Sci., 59, 69-86. http://dx.doi.org/10.1016/j.ecss.2003.08.002

Sow, I, \& Guillard, J. (2010). Suivi par hydroacoustique du peuplement piscicole d'une Aire Marine Protégée du Sine-Saloum (Sénégal): bilan 2003-2007. J. Sci. Hal. Aquat., 1, 21-32.

Thébault, E., \& Loreau, M. (2005). Trophic interactions and the relationship between species diversity and ecosystem stability. Am. Nat., 166, 95-114. http://dx.doi.org/10.1086/444403

Tilman, D., \& Downing, J. A. (1994). Biodiversity and stability in grasslands. Nature, 367, 363-365.

Tilman, D., Lehman, C. L., \& Thomson, K. T. (1997). Plant diversity and ecosystem productivity: Theoretical considerations. Proc. Natl. Acad. Sci., 94, 1857-1861.

Villéger, S. (2008). Dynamique de la diversité fonctionnelle des communautés de poissons (Lagune de Terminos, Mexique). Thèse de doctorat de l'université Montpellier II, Montpellier, France, $317 \mathrm{p}$.

Villéger, S., Miranda, J. R., Hernandez, D. F., \& Mouillot, D. (2010). Contrasting changes in taxonomic vs. functional diversity of tropical fish communities after habitat degradation. Ecol Appl 20, 1512-1522. 
Walker, S. C., Poos, M. S., \& Jackson, D. A. (2008). Functional rarefaction: estimating functional diversity from field data. Oikos, 117, 286-296. http://dx.doi.org/10.1111/j.2007.0030-1299.16171.x

Wantiez, L. (2002). Suivi temporal des récifs du Parc du Lagon Sud placés en réserves. Rapport université de la Nouvelle-Calédonie, Province Sud de la Nouvelle-Calédonnie, Nouméa, 112 p.

Wantiez, L., Thollot, P., \& Kulbicki, M. (1997). Effects of marine reserves on coral reef fish communities from five five islands in New Caledonia. Coral Reefs, 16, 215-224.

Wellnitz, T., \& Poff, N. L. (2001). Functional redundancy in heterogeneous environments: implications for conservation. Ecol. Lett., 4, 177-179.

Wiedmann, M. A., Aschan, M., Certain, G., Dolgov, A., Greenacre1, M., Johannesen, E., ... \& Primicerio, R. (2014). Functional diversity of the Barents Sea fish community. Mar Ecol Prog Ser, 495, 205-218. http://dx.doi.org/10.3354/meps10558

Winemiller, K. O. (1991). Ecomorphological Diversification in Lowland Freshwater Fish Assemblages from five biotic regions. Ecol. Monogr., 61, 343-365. http://dx.doi.org/10.2307/2937046

Winemiller, K. O., \& Kelso-Winemiller, L. C. (2003). Food habits of tilapine cichlids of the upper Zambezi River and floodplain during the descending phase of the hydrologic cycle. J. Fish Biol., 63, 120-128. http://dx.doi.org/10.1046/j.1095-8649.2003.00134.x

Woodward, G., Ebenman, B., Emmerson, M., Montoya, J.M., Olesen, M., Valido, A., \& Warren, J. M. (2005). Body size in ecological networks. Trends Ecol. Evol., 20, 402-409.

\section{Appendices}

Appendix 1. Values of standardized morpho-functional traits used to run the Ward method clustering analysis.

\begin{tabular}{|c|c|c|c|c|c|c|c|c|c|c|c|c|c|}
\hline & & $\log (W)$ & RGS & RGL & RDT & RED & BTS & PAR & PSC & CAR & PFP & RMP & PEP \\
\hline 3 & Arius latiscutatus & 2.79 & 0.47 & 0.24 & 2.31 & 0.45 & 0.84 & 0.61 & 3.23 & 0.24 & 0.25 & 0.27 & 0.77 \\
\hline 4 & Arius parkii & 2.66 & 0.28 & 0.15 & 0.12 & 0.41 & 0.88 & 0.66 & 3.09 & 0.24 & 0.16 & 0.32 & 0.75 \\
\hline 6 & Brachydeuterus auritus & 1.44 & 0.52 & 0.58 & 0.64 & 0.54 & 2.22 & 2.57 & 2.82 & 0.68 & 0.41 & 0.47 & 0.67 \\
\hline 7 & Caranx hippos & 3.62 & 0.16 & 0.17 & 0.24 & 0.23 & 2.45 & 0.47 & 9.83 & 0.25 & 0.37 & 0.28 & 0.63 \\
\hline 8 & Caranx senegalus & 2.12 & 0.08 & 0.22 & 0.61 & 0.39 & 2.94 & 1.18 & 8.39 & 0.55 & 0.39 & 0.35 & 0.54 \\
\hline 11 & Cynoglosus senegalensis & 2.42 & 0.07 & 0.00 & 0.48 & 0.08 & 0.16 & 0.0 & 0.00 & 0.0 & 0.0 & 0.0 & 1.00 \\
\hline 12 & Dasyatis $s p$ & 2.57 & 0.05 & 0.00 & 0.74 & 0.05 & 0.13 & 0.38 & 2.10 & 0.62 & 0.5 & 0.00 & 1.00 \\
\hline 13 & Dicentrarchus punctatus & 2.09 & 0.22 & 0.31 & 0.55 & 0.58 & 2.13 & 1.58 & 1.78 & 0.34 & 0.37 & 0.40 & 0.70 \\
\hline 14 & Diplodus bellottii & 1.41 & 0.10 & 0.05 & 0.62 & 0.43 & 2.76 & 2.07 & 2.26 & 0.66 & 0.39 & 0.33 & 0.64 \\
\hline 15 & Elops lacerta & 2.27 & 0.94 & 0.26 & 0.54 & 0.53 & 2.24 & 3.33 & 2.83 & 0.4 & 0.11 & 0.65 & 0.68 \\
\hline 16 & Ephippion guttifer & 3.23 & 0.11 & 0.02 & 1.14 & 0.28 & 1.55 & 0.20 & 2.50 & 0.13 & 0.59 & 0.30 & 0.83 \\
\hline 22 & Galeoides decadactylus & 1.94 & 0.29 & 0.29 & 0.54 & 0.54 & 2.15 & 1.38 & 2.52 & 0.46 & 0.24 & 0.16 & 0.61 \\
\hline 23 & Gerres nigri & 2.07 & 0.06 & 0.06 & 0.75 & 0.49 & 2.80 & 1.13 & 2.75 & 0.37 & 0.32 & 0.34 & 0.67 \\
\hline 24 & Hemichromis fasciatus & 2.20 & 0.22 & 0.05 & 1.48 & 0.26 & 2.18 & 0.8 & 1.74 & 0.28 & 0.36 & 0.40 & 0.82 \\
\hline
\end{tabular}




\begin{tabular}{|c|c|c|c|c|c|c|c|c|c|c|c|c|c|}
\hline 25 & Hemiramphus brasiliensis & 1.81 & 0.22 & 0.06 & 0.31 & 0.53 & 1.98 & 1.82 & 4.56 & 0.74 & 0.69 & 0.65 & 0.60 \\
\hline 28 & Liza falcipinnis & 2.22 & 0.17 & 0.20 & 4.0 & 0.64 & 2.08 & 0.95 & 2.12 & 0.29 & 0.69 & 0.30 & 0.38 \\
\hline 29 & Liza grandisquamis & 2.08 & 0.16 & 0.24 & 2.86 & 0.63 & 1.66 & 1.29 & 2.04 & 0.3 & 0.63 & 0.29 & 0.39 \\
\hline 31 & Monodactylus sebae & 1.83 & 0.11 & 0.12 & 1.32 & 0.44 & 8.41 & 0.84 & 3.19 & 0.51 & 0.37 & 0.48 & 0.56 \\
\hline 32 & Mugil bananensis & 2.11 & 0.04 & 0.16 & 3.94 & 0.69 & 0.52 & 1.25 & 2.36 & 0.39 & 0.65 & 0.35 & 0.43 \\
\hline 33 & Mugil cephalus & 2.26 & 0.15 & 0.23 & 4.12 & 0.59 & 1.86 & 1.33 & 2.44 & 0.36 & 0.70 & 0.42 & 0.48 \\
\hline 36 & Pomadasys incisus & 1.64 & 0.16 & 0.08 & 0.74 & 0.51 & 2.43 & 1.99 & 2.91 & 0.57 & 0.36 & 0.34 & 0.66 \\
\hline 37 & Pomadasys jubelini & 2.46 & 0.16 & 0.07 & 1.36 & 0.39 & 2.50 & 0.94 & 2.37 & 0.28 & 0.38 & 0.4 & 0.79 \\
\hline 38 & Pomadasys perotaei & 2.49 & 0.17 & 0.10 & 0.91 & 0.49 & 2.49 & 0.86 & 2.57 & 0.28 & 0.36 & 0.23 & 0.73 \\
\hline 39 & Pseudotolithus brachygnathus & 2.14 & 0.31 & 0.28 & 0.62 & 0.44 & 2.03 & 1.59 & 1.82 & 0.28 & 0.41 & 0.43 & 0.75 \\
\hline 40 & Pseudotolithus elongatus & 2.08 & 0.1 & 0.19 & 0.53 & 0.43 & 0.82 & 1.36 & 1.95 & 0.28 & 0.43 & 0.24 & 0.82 \\
\hline 41 & Pseudotolithus typus & 1.72 & 0.58 & 0.23 & 0.66 & 0.35 & 1.72 & 2.59 & 1.51 & 0.36 & 0.46 & 0.50 & 0.89 \\
\hline 47 & Trachinotus teraia & 3.13 & 0.13 & 0.07 & 0.80 & 0.37 & 4.76 & 0.39 & 5.36 & 0.22 & 0.43 & 0.18 & 0.49 \\
\hline 48 & Tylosurus crocodilus & 2.63 & 0.50 & 0.00 & 0.31 & 0.56 & 1.18 & 0.73 & 6.55 & 0.46 & 0.53 & 0.61 & 0.61 \\
\hline
\end{tabular}

Code significations are referenced in Table 1.

Appendix 2. Parameters used to calculate the Functional Redundancy Index (RFI) from 2003 to 2007. Codes: FR: species richness in a functional group; $\mathrm{Ni}$ : species abundance in a functional group; $\mathrm{Pi}=\mathrm{Ni} / \mathrm{Nt}$ where $\mathrm{Nt}$ is identified as the abundance of total fish assemblages

\begin{tabular}{|c|c|c|c|c|c|c|c|c|c|c|c|c|c|c|c|c|c|c|c|c|}
\hline \multirow[t]{2}{*}{ Functional guilds } & \multicolumn{4}{|c|}{2003} & \multicolumn{4}{|c|}{2004} & \multicolumn{4}{|c|}{2005} & \multicolumn{4}{|c|}{2006} & \multicolumn{4}{|c|}{2007} \\
\hline & FR & $\mathrm{Ni}$ & $\mathrm{Pi}$ & PiFR & FR & $\mathrm{Ni}$ & $\mathrm{Pi}_{\mathrm{i}}$ & PiFR & FR & $\mathrm{Ni}$ & $\mathrm{Pi}$ & PiFR & FR & $\mathrm{Ni}$ & $\mathrm{Pi}$ & PiFR & FR & $\mathrm{Ni}$ & $\mathrm{Pi}$ & PiFR \\
\hline Algivorous / Detritivorous fish & 7 & 1564 & 0.08 & 0.01 & 7 & 532 & 0.02 & 0 & 5 & 266 & 0 & 0 & 5 & 500 & 0.03 & 0 & 6 & $\begin{array}{c}20 \\
6\end{array}$ & 0.01 & 0 \\
\hline Benthopelagic fish & 10 & 11552 & 0.62 & 0.06 & 11 & 15628 & 0.71 & 0.06 & 7 & 33046 & 0.93 & 0.13 & 8 & 11366 & 0.73 & 0.09 & 9 & $\begin{array}{l}77 \\
08\end{array}$ & 0.56 & 0.06 \\
\hline Zoobenthos feeders & 5 & 1410 & 0.07 & 0.01 & 7 & 3486 & 0.15 & 0.02 & 7 & 894 & 0.02 & 0 & 6 & 302 & 0.01 & 0 & 4 & $\begin{array}{l}15 \\
70\end{array}$ & 0.11 & 0.02 \\
\hline Demersal and Ichtyobenthophagous fish & 17 & 3882 & 0.2 & 0.01 & 18 & 2196 & 0.1 & 0 & 16 & 1172 & 0.03 & 0 & 17 & 3206 & 0.2 & 0.01 & 17 & $\begin{array}{l}42 \\
32\end{array}$ & 0.3 & 0.01 \\
\hline Annual Functional Diversity & 39 & & & & 43 & & & & 35 & & & & 36 & & & & 36 & & & \\
\hline Functional Redundancy Index & \multicolumn{4}{|c|}{9.7} & \multicolumn{4}{|c|}{10.3} & \multicolumn{4}{|c|}{7.1} & \multicolumn{4}{|c|}{8.7} & \multicolumn{4}{|c|}{8.9} \\
\hline
\end{tabular}

\section{Copyrights}

Copyright for this article is retained by the author(s), with first publication rights granted to the journal.

This is an open-access article distributed under the terms and conditions of the Creative Commons Attribution license (http://creativecommons.org/licenses/by/3.0/). 